Historic, Archive Document

Do not assume content reflects current scientific knowledge, policies, or practices. 

Annual Catalog and Price List

Economic and Ornamental Fruit Trees and Plants

Panama Rhubarb, Berries, Vegetable and Flower Seeds

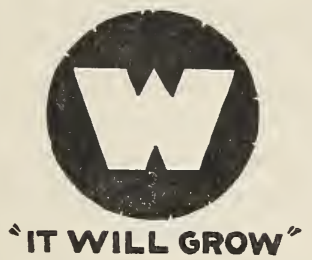

WAGNER NURSERIES 2491 EAST COLORADO STREET PASADENA, CAL. 


\section{Winter Rhubarb}

Winter producing rhubarb was originated and introduced by Luther Burbank some twenty-five years ago and was called Burbank Crimson Winter, the bulk of his stock of plants being sold to Mr. J. B. Wagner some two or three years after they were introduced and were propogated by him for several years. By continual crossing and hybridizing, new varieties were secured out of which one was selected that was called Wagner's Giant Crimson, which after several years of testing and propogating was placed on the market and for a number of years has been the leading commercial variety of winter rhubarb.

The next step forward in the production of an improved winter variety was the introduction of the Panama variety some three years ago and it is fast replacing any and all sorts of rhubarb that is grown for commercial purposes.

Anyore planting rhubarb in a commercial way makes a very serious mistake in planting anything but the winter producing varieties as the summer varieties will only bear during a short period in the early spring and summer, while the winter bearing varieties will produce continuously throughout the entire year.

Winter rhubarb is unquestionably profitable if one has the proper conditions for its growth. We do not recommend planting winter rhubarb with the exception of large winter returns where severe frosts are experienced. The lighter soils are preferred as they are usually the warmer soils, but rhubarb can be grown on quite heavy soil if continuous cultivation is practiced. The richer the soil, the better for rhubarb culture as it is an unknown incident where too much fertilizer has been given.

The rhubarb plants may be set at any season of the year with the exception of the month from the fifteenth of December to the fifteenth of January, which is usually the coldest season of the year and during which time if planted, and the ground for any reason is not well drained, the plants are very apt to decay.

Rhubarb planted prior to the first of September should produce a marketable crop the following February and we often recommend planting any time the ground is ready as the sooner the plants are in, the sooner one will obtain marketable crops, and if this crop should come during a period of low prices, which is usually between June and September, there is absolutely no loss as the plants will be just that much larger and stronger for the spring crop.

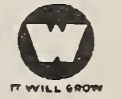

\section{Wagner Rhubarb}




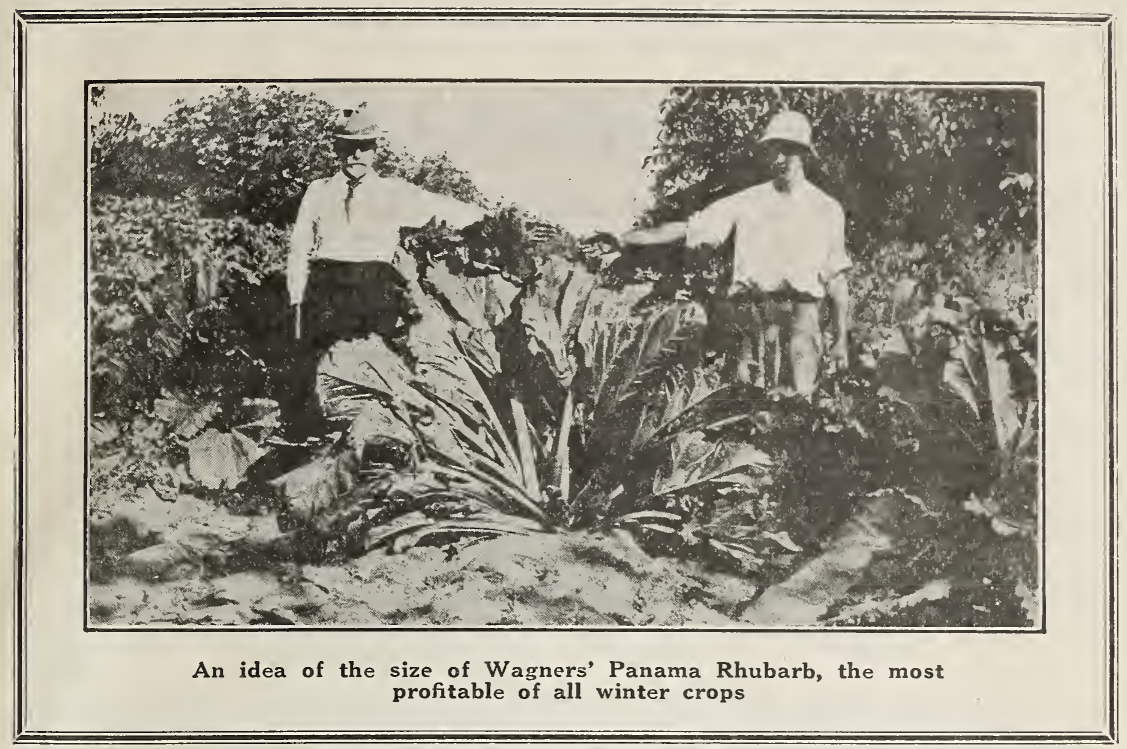

\section{Wagner's Panama Rhubarb}

\section{The Greatest of all Winter Crops}

Wagner's Panama Rhubarb. We offer herewith the best rhubarb it is possible to grow. We have experimented with rhubarb for twenty-five years and are responsible for every named variety of Winter Rhubarb that is now offered to the public, of which Wagner's Panama is supreme. It produces as high as twenty tons per acre and very strongly resembles the strawberry rhubarb. but, unlike the Strawberry variety, it produces over the entire year and is at its best during February and March when prices of $\$ 2.00$ and $\$ 3.00$ per box of 30 pounds is obtainable.

lt should be planted from subdivisions, the same as all other winter varieties; seedlings do not reproduce. The plants should be set any time from January to November and planted in well prepared ground. Set the crowns of the plants not to exceed onehalf inch under the surface of the ground. lrrigate when planted and keep well cultivated at all times. Price, $35 \mathrm{c}$ each; $\$ 3.50$ per dozen; $\$ 25.00$ per $100 ; \$ 150.00$ per thousand.

Wagner's Giant Amber Winter. A cross of Burbank's Crimson Winter and the Golden Syrup, one of the best amber colored winter rhubarbs. Extremely hardy variety. Recommended for sections where climate is questionable as it stands excessive heat and colds better than any known sort. Excellent for cooking. Each, 20c; dozen, \$1.50; hundred, \$8.00; thousand, $\$ 60.00$.

Wagner's Giant Crimson Winter. Noted for length of stem which often weighs $11 / 4$ pounds. We have picked at one time from a single plant 60 full grown stems that weighed 30 pounds. This variety does not run much to seed; to get the plants the crowns have to be subdivided. The stems are as tender as any known plant and have good color; does not have to be peeled for cooking. The best growing season is from October until June. Some dealers divide old Giant Seedlings and sell them for true subdivisions. It will pay you to demand the genuine. Each, 20c; dozen, \$1.50; hundred, $\$ 8.00$; thousand, $\$ 60.00$.

Wagner's Giant Seedling. Not recommended for general commercial planting. Being grown from seed of the famous giants they yield up to 20 tons per acre. Each, 15c; dozen, $\$ 1.00$; hundred, $\$ 6.00$; thousand, $\$ 40.00$.

Wagner's Cherry. A dark red stalk and good producer, but not as strong a winter grower as the amber. Each, 30c.

\section{Summer Varieties}

Improved Strawberry. One of the best adapted to the North Coast sections and extensively grown in rhubarb sections a round San Lorenzo. The stems are not of a red color as one would think but are green; if bleached are of a pink color. Cropping season, March to July. Each, 15c; dozen, $\$ 1.25$; hundred, $\$ 4.00$.

Wagner's Improved Lineaus. An improvement over the old Myatt's Lineaus. Heavier producer, stalks heavier and thicker and comes 10 days earlier. You can make no mistake in planting this variety for early Spring and Summer crops, as it is a heavy yielder and the best summer variety grown by us. Each, 20c; dozen, $\$ 1.50$.

Riverside Giant. An excellent variety. Stalks crisp and tender. A very good commercial rhubarb. Excellent for cooking; when cooked the skin disappears. Cuttings of this variety are made from the month of March and continues through the summer of March and contint of stalk is a bright red color and of largest size. Each, $20 \mathrm{c}$; dozen, $\$ 2.00$. 


\section{Winter Rhubarb Growing}

Winter Rhuharb. Starts to grow vigorously by October and produces stalks continually until after common varieties niake their first appearance some six months later. If kept moist will produce stalks abundantly at all seasons; it is, in fact, absolutely perpetual. For growing in California and shipping East, it has proven to be more profitable than anything the soil produces. Never plant seed or seedlings for commercial use if true subdivisions are obtainable. It deteriorates rapidly when far removed by use of seedlings from original.

\section{THE GREATEST MONEY CROP IN CALIFORNIA}

Plant 2 by 5 feet. Recent experience indicates this is best distance to plant; $2 \times 5$ feet requires 4.335 per acre. By planting close in row it causes stems to grow longer and more tender and in no way is injurious while more and redder stems are produced from same area. Also the dense foliage protects stems from frost during winter and shades the ground during hot weather. Where it is desired to cultivate the ground both ways, plant $3 \times 4$ feet. This requires 3,660 plants to the acre.

\section{PREPARATION OF THE GROUND AND FERTILIZING}

If manure is to be applied before planting, scatter it broadcast, and work it into the ground well before planting. Never fill a furrow with manure and then plant the roots in the furrow as it is apt to rot the plant. If manure is to be applied after planting do not apply until the plant starts to grow by beginning to sprout, then drill the manure in the furrows about 4 inches from the plants and cover. Do not be afraid to fertilize as it is improbable that you will give it too much. Nitrate of Soda is the best commercial fertilizer for rhubarb but should be applied only about two months before crops are desired and at the rate of 300 pounds per acre, applied in furrows and covered, it is necessary that the ground be wet to make it available to the plants. PLANTING--Ground should be in well tilled condition; draw furrows with hand plow where plants are to be set and irrigate the furrows; as soon as the ground is dry enough to work on (12 to 18 hours) set the plants in the bottom of the furrow at a depth that will leave the top of the plant about $1 / 2$ inch below the surface of the ground when the furrows are filled in. lrrigate the furrow immediately after planting and as soon as dry enough to work the furrows should be filled in covering the plants over to about the depth of $1 / 2$ inch, rake the ground so it will be pulverized. lrrigate and cultivate every 10 days for the first two months then as often as you deem necessary to keep the ground moist near the crown.

Contrary to the general opinion a large rhubarb sub-division or seedling is not the best to plant, as the root that is planted does not grow but merely keeps the crown alive until the eyes start to grow and send out new roots, and the old root that was planted decays and the plant lives and grows from the roots near the surface of the ground. This is the reason and necessity to keep the ground moist near the crown of the plant for the first two months so as to keep the new fibre roots from becoming dry which of course will die if not kept moist. Be sure and do not have the crown more than $1 / 2$ inch below the surface of the soil as if they are they will only make a weak growth and in most cases will die after one or two attempts of growing. Winter Rhubarb may be planted successfully any time of the year, but for commercial plantings we recommend from February to October.

We feel confident that any one planting Rhubarb on a commercial basis will not be disappointed in their venture. We have given above, information that will enable you to judge for yourself as to whether or not you can succeed in making money growing rhubarb for profits. We are ready at all tirnes and are willing to give you information on the growing and culture of rhubarb in a commercial way, as we have been in the business twenty years growing and experimenting with rhubarb, and you are assured of our sincere desire to advise with you.

Mr. J. B. Wagner originated all the varieties of Winter Rhubarb grown commercially today, and in his 20 years experimenting work has tested every known sort from every part of the world where rhubarb is grown. In all about 250 varieties which has been used in hybridizing and crossings with results as set forth herein, this was accomplished largely through the efforts of our U. S. Agricultural Department at Washington, D. C., who, as well as our State Agricultural and Horticultural Organizations generally recognize Mr. J. B. Wagner as the best authority on rhubarb in the world today.

We have endeavored in above treatise to answer all of the leading questions commonly asked by intending purchasers. In case there is any further information regarding soil or other conditions desired on the subject, write us and we will be pleased to answer any direct queries not herein covered. We carry one of the largest assortments of berry and small fruit plants to be found in the State. Kindly give same careful attention and submit a list of your wants. Our rhubarb, berry and small fruit experimental grounds are open to the public--you are invited to visit them at any time. 


\section{Blackberries}

Advance Blackberry. The earliest of all blacks and a good berry, but sometimes a shy bearer. A very good keeper and grown much for early shipment. Each, 20c dozen, $\$ 2.00$; hundred, $\$ 10.00$.

Cory's Thornless Mammoth. The earliest and largest blackberry grown. The foliage and habit of growth are identical with the Mammoth. Should be trelised for best results. The fruit is of immense size, long and in every respect resembles the Mammoth, for which it is often mistaken, but the fruit averages larger and has a better flavor, having a distinct Black Cap Raspberry flavor. Hardy anywhere, very small seeds; excellent for table and canning, jelly or jam. A flavor all its own and simply superb; served in many ways. A good shipper and market berry. Each, 15c; dozen, $\$ 1.25$; hundred, $\$ 8.00$; thousand, $\$ 60.00$.

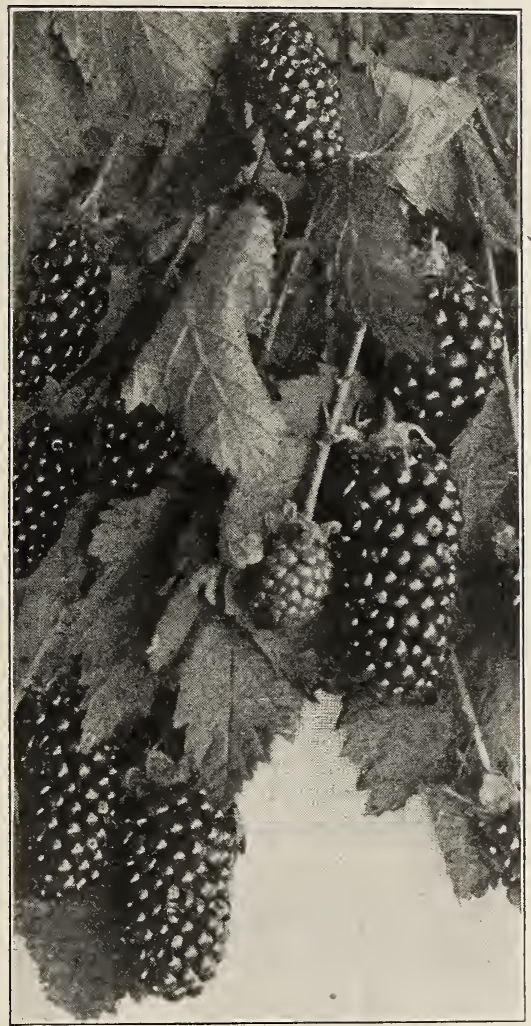

MAMMOTH BLACKBERRY

\section{STANDARD VARIETIES}

Burbank Thornless. The latest and sweet est of all blackberries; comes at a time when there is no other. Each, $15 \mathrm{c}$; dozen, $\$ 1.25$; hundred, $\$ 8.00$.

Crandall Blackberry. Early, strong upright grower; no trellising needed. Heavy producer; fruit medium size, roundish, jet black fine flavor. Each, 10c; dozen, \$1.00; hundred, $\$ 5.00$.
Himalaya Blackberry. Late, long season cropper; begins to ripen with the last o the others. Does not die back after fruit ing, but continues to grow for many years like a grape vine. Should be trellised. Berry medium, round; fine flavor, jet black. Good for canneries. Fruit right up to frost. Plant $6 \times 10$ feet. Each, 10c; dozen, $\$ 1.00$; hundred, $\$ 6.00$.

Mammoth Blackberry. Early, begins to ripen right after Cory. Fruit of the largest size, very long and black. Should be trellised. Plant $5 \times 7$ feet. Each, 10c; dozen $\$ 1.00$; hundred, $\$ 7.00$.

Lawton Blackberry. Medium early, very similar to the Crandall in habit though canes grow stronger and not so weeping. A good producer with fine fruit. Plant $3 \times 6$ feet. Each, 10c; dozen, \$1.00; hundred, $\$ 6.00$.

Iceberg. (White Blackberry.) An amber colored blackberry, medium size, good but different flavor from other blackberries. The habit of vine is similar to the Lawton. Very prolific. Plant $4 \times 6$ feet. Each, 15c; dozen, $\$ 1.50$.

\section{Dewberries or Trailing Blackberries}

The earliest of any blackberry; begins to ripen in May in this section.

Wagner Rose Dewberry. The earliest Dewberry; in fact, the first of any of the climbing berries to ripen. An excellent keeper and shipper, and the best money making berry. The crop is all picked before any other berry is ready to pick. Each. $25 \mathrm{c}$; dozen, $\$ 2.00$; hundred, $\$ 10.00$.

Austin Dewberry. The earliest of all known Dewberries; very prolific and profitable in most soils and locations. Hardy anywhere. Each, 15c; dozen, $\$ 1.50$.

Gardena Dewberry. Extra early, begins ripening ahead of the Mammoth. it is the heaviest yielder of any of the family. Fine flavor; good for table use. Plant $3 \times 5$ feet. Each, 10c; dozen, $\$ 1.00$; hundred, $\$ 5.00$.

Lucretia Dewberry. The only late Dewberry worthy of planting. Comes in after the Gardena. Plant $3 \times 5$ feet. Each, 10c; dozen, $\$ 1.00$; hundred, $\$ 5.00$.

\section{Loganberries}

Loganberry. A cross between the Raspberry and the Blackberry. Quite tart unless very ripe. Unexcelled for table use, jam, jell, canning or drying. Trailing in habit like the Mammoth and should be planted and treated in the same manner. Begins ripening shortly after the Mammoth. Plant $5 \times 6$ feet. Tips each, 10c; dozen, $75 \mathrm{c}$; hundred, $\$ 6.00$.

\section{Phenominal Berry}

Phenominal Berry. Similar to the Logan except a trifle larger and has less acid. Plant $5 \times 6$ feet. Each, 15c; dozen, \$1.50; hundred, $\$ 10.00$; thousand, $\$ 75.00$.

\section{Red Raspberries}

California Surprise. The earliest and most productive of any Raspberry. Where climatic conditions will permit, this sort can be picked every month of the year. Hardy in any section where it does not get below zero. Fruit medium size, good color and flavor unsurpassed. We recommend it in preferance to any other. Each, 10c; dozen, $75 \mathrm{c}$; hundred, $\$ 5.00$. 


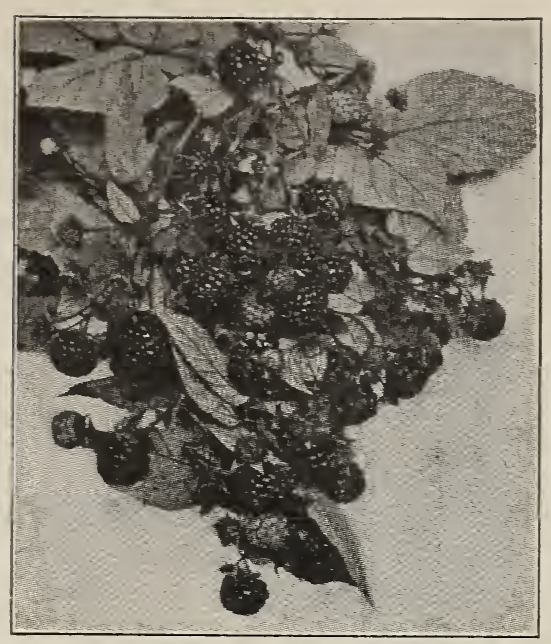

CUTHBERT RASPBERRY

-

Cuthbert. Red, medium to late. Has been the standard for over fifty years. Does extra well in most sections of the Pacific States. Fruit large, firm and fine quality. Each, 10c; dozen, $75 \mathrm{c}$; hundred, $\$ 5.00$.

Superlative. Medium early, large red fruit. Vigorous grower. Preferred to most others in the Northern Coast sections where excessive rains occur. Each, 10c; dozen, $\$ 1.00 ;$ hundred, $\$ 7.50$.

St. Regis. Recent introduction; fruit a bright crimson; a long season cropper; early to quite late. Firm flesh, a good shipper. Hardy anywhere. Each, 10c; dozen, 75c; hundred, $\$ 5.00$.

Ranere. An excellent everbearing red raspberry. A good variety. Berries can be picked from early in season until the early frosts. Each, 10c; dozen, \$1.00; hundred, $\$ 7.00$.

Wagner's Everbearing Golden Queen. It almost identical with Cuthbert except color, it being beautiful yellow. Heavy producer, first class quality. It is one of the finest berries grown for flavor and bearing qualities. We have never grown or tasted a berry of better flavor. Try a few. Each, $15 \mathrm{c}$; dozen, $\$ 1.50$.

La France. Great red everbearing. New, thoroughly tried, very promising. Very large bushes, berries slightly larger than ordinary. Like St. Regis bears all season with heavy fall crop. Each, 30c; dozen, $\$ 3.00$.

\section{Black Raspberries}

Each, 10c; Dozen, \$1.00; Hundred, $\$ 6.00$; Thousand, $\$ 40.00$

Columbian Purple. One of the sweetest and best raspberries for table use or coking.

Plum Farmer. Berry large and attractive, and excellent market berry.

King of the Cliff. A good variety of Black Cap for home and commercial use. ls fast becoming a popular berry in this section.

Cumberland. A vigorous growing variety, very productive. Jet black fruit; somewhat longer in season than the Plum Farmer.

Munger. One of the leading sorts.

\section{Strawberries}

Each, 5c; Dozen, 25c; Hundred, \$1.50; Thousand, $\$ 8.50$, Unless Otherwise Noted

Banner Strawberry. Resembles in almost every respect the New Oregon. While there may be some slight variation in these two varieties as grown in certain sections our experience here has been that they are practically one and the same berry.

New Oregon Strawberry. Destined to be the coming commercial strawberry. It produces a vigorous upright growth that bears extremely early and abundantly. Practically immune to any insects, pests and diseases; bears from two to three years longer than any other known variety. Price, $10 \mathrm{c}$ each; $50 \mathrm{c}$ per dozen; $\$ 1.50$ per $100 ; \$ 10.00$ per thousand.

Brandywine. Perfect, large roundish conical, bright red, firm and rich flavor medium to late. Its size and color attracts everyone.

Carolina. A new variety far superior to most. It is earlier, bearing continuously throughout the summer and fall months. Plants will bear a full crop of berries eight to twelve weeks after planting. We advise planting this variety where quick returns are wanted for home or commercial use. Dozen, 30c; hundred, $\$ 2.00$; thousand, $\$ 9.00$.

Klondike. Perfect; very vigorous grower, hardy anywhere; rust proof. Fruit large, uniform, blood-red, juicy and of delicious flavor. Stands drought well. A favorite with market growers and the canneries, both East and West.

Marshall. A firm, red berry, good keeper and one of the standard commercial varie. ties. Can be planted in adobe soil with good results. Dozen, $50 \mathrm{c}$; hundred, $\$ 1.50$; thousand, $\$ 10.00$.

Progressive Everbearing. The most vig. orous growing plant of all the Everbearing Strawberries. Plant and fruit closely resemble Dunlap. The berries are produced in great abundance and are of extra fine flavor, the latter depending upon conditions of soil and climate. It is a good variety for home and commercial use. Dozen, $50 \mathrm{c}$; hundred, $\$ 3.00$; thousand, $\$ 15.00$.

Arizona Everbearing. A new everbearing; introduced by us some years ago. The largest fruit of any everbearing and of finest quality; bears until frost, and a heavy crop at all times; one of the best. Dozen, $35 \mathrm{c}$; hundred, \$2.00; thousand, \$12.00.

\section{Gooseberries}

Each, 25c; Dozen, \$2.00; Hundred, \$10.00

Oregon Champion. Large brownish red. Strong grower, heavy bearer. Plant $3 \times 5$ feet.

Downing. Yellowish green, extra large, strong grower, prolific bearer. Plant $3 \times 5$ feet.

Wágner's Improved Houghton. Enor. mously productive. Vigorous, slender, preading growth, the fruit hanging thick on the under side of the branches. Fruit a good size, smooth, pale red, or purple when ripe. It is the only variety we can recommend to withstand our hot interior valley section. The most profitable of all gooseberries. 


\section{Currants}

Each, 25c; Dozen, $\$ 2.00$; Hundred, $\$ 10.00$

Perfection. Recent introduction. Everything good that can be said of a red currant seems to apply to the Perfection. Plant $3 \times 4$ feet.

Fay's Prolific Red. One of the old standards which is hard to beat. Produces im. mense crops of fine fruit. best.

Cherry. Red. Large fruit. One of the

Wilder. Red. Vigorous, upright growing bush, hardy and productive. Fruit large, grows in fine large clusters; excellent quality. We consider this the best of all currants as a cropper and money maker.

Lee's Prolific. Black. The leading variety in the black sorts.

Black Booskoop Giant. Decidedly larger and hardier than any other black variety. Does well in hot sections.

\section{Eastern Grapes}

Each, 25c; Dozen, \$2.00; Hundred, \$15.00

Concord. The best known and popular of all grapes. Best for table, wine and market; succeeds over a great extent of country.

Catawba. Well known as the great wine grape of Ohio, Kentucky, etc. Bunches large and loose; berries large, of a coppery red color. Two weeks later than Concord.

Delaware. Still holds its own as one of the finest grapes. Bunches small, compact, berries rather small; skin thin, light red; very juicy, without any hard pulp.

Niagara. This white grape is justly regarded as one of the very best known; very fine quality for a table grape; very prolific, hardy and of fine flavor.

Worden. A seedling from the Concord which it greatly resembles in color and appearance. lt is, however, several days earlier; much more delicious and melting and has a flavor that is equaled by no other grape grown. Berries and clusters are very large and compact; vine is fully as hardy as the Concord and more productive. It is a sure bearer.

Isabella. Berries large, round, dark purple; sweet and rich. Succeeds well in California.

Moore Early. Similar to Concord in appearance and quality, but two weeks earlier. Vine healthy, hardy and succeeds wherever Concord grows.

\section{Grapes}

Each, 15c; Dozen, \$1.25; Hundred, \$6.00, Unless Otherwise Noted

Malaga. Very large bunches, of ten weighing 10 pounds; fruits very large oval; yellowish green. A good shipping variety, commanding a high price in the eastern markets.

Muscat. Oblong, light transparent yellow with heavy bloom that gives an attractive finish when dried. The most important raisin grape in California.

Thompson Seedless. Medium size, yellow berries, large bunches. Entirely seedless. Strong grower, heavy producer. The finest seedless raisin grape and fine for arbors.

Black Monukka. A black seedless grape, rapidly coming into favor; about one-third larger than the Thompson seedless; berries of even size; color, dark red to black when fully ripe; quality excellent; bunches loose but large; bears well and vine is vigorous grower. Early August. Each, 30c; dozen. $\$ 3.00$.

Rose of Peru. Very large, brownish black; flesh tender, juicy, rich and sprightly. The vine is a strong grower and does well on a trellis. September.

Emperor. A large, late purple, oval berry in large loose bunches. A vigorous grower and good shipping variety.

Black Hamburg. A fine tender table grape producing large compact bunches. A great favorite for table and market.

Tokay. Flaming Tokay. Large, red ber ries in large bunches, heavy bloom.

Black Hamburg. A fine tender table grape, producing large compact bunches.

Black Morocco. Berries very large oval, purplish black when ripe; flesh firm, sweet and crisp. This is an excellent late ship. ping grape.

Cornichon. Long, loose bunches; oval, tapering at both ends; firm and of fine flavor; ripens late and is a splendid sort for shipping.

\section{Wine Grapes}

Also Fine for Table. Each, 20c; Dozen, $\$ 1.50$; Hundred, $\$ 8.00$

Mission. This is the grape introduced in the early mission days and is widely distributed, thriving in most every section of California. Medium size, dark blackish purple. Very sweet and delicious.

Zinfandel. Dark purple grapes in large compact bunches. Has heavy bloom. Thrives under any average condition. This was one of the leading claret grapes in California.

Mataro. Is somewhat similar to the Mission Grape and is very popular; is also one of the finest and best shipping grapes known.

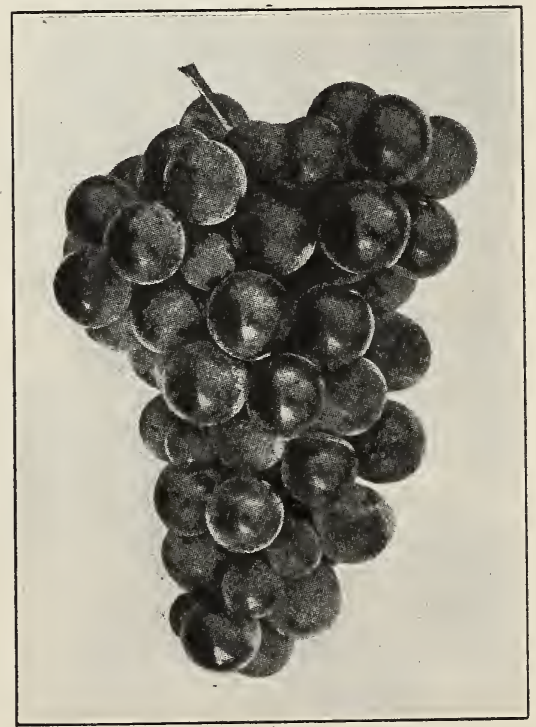

NIAGARA GRAPE 


\section{Plant Guavas}

It is the last fruit we have in the fall after all other fruits are gone, unsurpassed for eating raw, cooked, or in jell or jam, makes a beautiful evergreen hedge, set 2 to 3 feet apart. It fruits heavy and young.

Strawberry Guava. (Red.) Round; deep claret color, strawberry flavor. A low growing bush. Never trim or try to train its habit of growth. You cannot make a tree of it and get good fruit. 18" $-24^{\prime \prime}, 50 \mathrm{c}$ each. Small in pots, $25 \mathrm{c}$ each, $\$ 2.00$ per dozen.

Strawberry Guava. (Yellow.) Same in every respect as the red, except the fruit averages much larger and is a beautiful golden yellow; not so acid as the red strawberry guava; to our mind it is much finer fruit in every respect. 12"-18", 25 c each, $\$ 2.00$ per dozen. $2-3$ feet, 50 c.

Feijoa. (Pineapple Guava.) Absolutely one of the finest fruits on earth. Really indescribable. Eat a ripe one and you will eat more if you can buy or raise them. The plant is quite hardy and has stood zero weather out doors. It ripens late in the fall the same as the others. Greenish yellow when ripe and frequently as large as a hen egg. The flavor seems to be a mingling of the pineapple, raspberry, and banana. In eating it, one is reminded of the old easter May apple or May pop. lt is a fine ornamental as well, its bright glossy green leaves remaining on the plant all the year. The blossom is very pretty showing pure white beneath and purple above. Well worthy a place for flower alone; makes pretty hedge. Plant a few and have them for show and value. $12^{\prime \prime}-18^{\prime \prime}, 25 \mathrm{c}$ each, $\$ 2.00$ per dozen, $\$ 10.00$ per hundred. $18^{\prime \prime}-24^{\prime \prime}, 35 \mathrm{c}$ each. $3-4$ feet in cans, $75 \mathrm{c}$ each. 4 feet and up in cans, $\$ 1.00$. A few budded trees in cans, $\$ 1.50$ each.

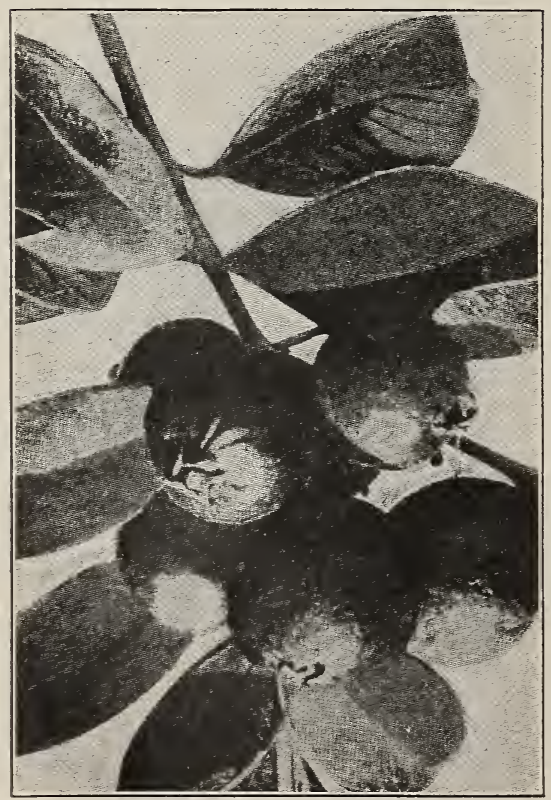

STRAWBERRY GUAVA

\section{Cherimoya}

Cherimoya. (Custard Apple.) Stands about as much cold as the orange and makes a large spreading drooping tree. Never sheds its foliage unless frozen. Evergreen in some sections. The fruit often weighs $1 \frac{1 / 2}{2}$ pounds. The flesh is more the consistency of ice cream and has a delicious indescribable flavor all its own. 18 to 24 inches in pots, $75 \mathrm{c}$.

\section{Sapote}

Sapote. (Casimiroa Edulis.) A large fast growing tree; five-fingered, sharp-pointed foliage. Quite tender for frost, but quickly recovers. Fruit yellowish or gray green; yellow or white pulp with several good sized seeds. Flavor difficult to describe; has a suggestion of the Eastern pawpaw. Tree remarkably drought resistant. Small, \$1.00.

\section{Citrus and Tropical Fruits}

Dancy. Tangerine. The most productive and profitable for shipping. Size about same as Satsuma, slightly thicker. Ripe February to August. $\$ 3.50$ each.

Eureka Lemon. Leading commercial lemon. Fruit uniform and of medium size, rind of fine texture and color; rich in juice; quality the highest. $\$ 2.00$ each.

Marsh Seedless Pomelo. Fruit of good size and practically seedless. Juice abundant and of exceptionally fine flavor, rich and piquant; rind thin and lemon yellow in color. Tree a vigorous and compact grower and good bearer. March to October. \$2.25 each.

Washington Navel Orange (Seedless.) Easily heads the list of California oranges, and by reason of its superiority, is largely responsible for California's world-wide citrus fame. Peel smooth and tough making it an ideal shipper. Ripens November to March. $3 / 4$ " up, $\$ 2.00$ each.

Valencia. The only variety that shares the popularity of the Washington Navel. As the Navel season closes the Valencia season begins and continues through the summer and fall months. Tree strong, vigorous grower, very prolific; fruit medium size, oblong, firm and heavy; few seeds. Having no competitor when it reaches the market commands good price. Ripens April to October and hangs on tree all winter. $5 / 8$ ", $\$ 1.00$ each; 3/4", \$1.50 each; under $1 / 2 "$, $75 \mathrm{c}$ each.

\section{Avocados}

Wagner's Seedling. The hardiest and most prolific sort known. Fruit the true Mexican type, skin is thin, dark glossy purple when ripe. It has a small sized seed that fits tight in the cavity. Flesh yellow and has a rich flavor. Ripens September and October; a recommended variety. $25 \mathrm{c}$ to $\$ 1.00$ each.

Fuerte. Fruit pear shaped dull and green in color, matures at an exceptionally good time. Samples of the fruit analyzed as high as $30 \%$ fat or oil being one of the highest yet tested. Together with all its other good qualities it ranks as one of the best. Fruit from ten to sixteen ounces. Ripens January to March. $3-4 \mathrm{ft}$., $\$ 4.50$ each; $4-5 \mathrm{ft}$., $\$ 6.50$ each.

Lyon. Pyriform shape, skin moderately thick and somewhat rough, dark green in color with numerous small yellowish or russet spots. Flesh a deep cream tinged with green toward the skin; has a rich pleasant flavor; medium size seed fitting tight in cavity. Ripens April to August. 3-4 feet, $\$ 4.50$ each; 4.5 feet, $\$ 6.50$ each 
Pueblo. $1 \mathrm{t}$ is the smallest of the recommended varieties, weighing from six to fourteen ounces with a medium-sized seed which fits tightly in the cavity. The flesh is yellow, smooth and of a rich flavor. At a period of eight months from blossom to maturity of the fruit is the shortest of any of the recommended varieties. We recommend very highly for family use. Ripens in December and January. 3.4 feet, $\$ 4.50$ each; 4.5 feet, $\$ 6.50$ each.

\section{Loquats}

We list below four varieties of loquats, 2 yellow and 2 white varieties, and you can make no mistake in planting commercially any of the 4 varieties but we highly recommend the Wagner's Yellow Pear as being the peer of all others.

Wagner's Yellow Quince. Originated by J. B. Wagner, The shape is the same as a quince and can be readily mistaken for a quince. Has light tart and is extra large. One of the best for jellies and for commercial markets; heavy producer. An excellent combination in planting the two varieties originated by $\mathrm{Mr}$. Wagner. Both varieties have proven their merits. Under 2 feet $75 \mathrm{c} ; 2.3$ feet, $\$ 1.00$ each; 3.4 feet, $\$ 1.25$ each; 4 feet up, $\$ 1.75$ each.

Pineapple. (Originated by Mr. C. P. Taft.) A white variety, round, has been proven a good variety, sweet and juicy, $1-2$ feet, $50 \mathrm{c} ; 2.3$ feet, $75 \mathrm{c}$ each; $3-4$ feet, $\$ 1.00$ each; 4 feet up, $\$ 1.50$.

Blush. (Originated by Mr. C. P. Taft.) White variety, long, a good variety and good bearer. Sweet and juicy. Under 2 feet, $50 \mathrm{c}$ each; $2-3$ feet, $75 \mathrm{c}$ each; 3.4 feet, $\$ 1.00$ each; 4 feet up, $\$ 1.50$.

Wagner's Yellow Pear. (Originated by J B. Wagner.) Looks like a medium sized yellow pear. Luscious and sweet, produces the largest fruit and the smallest amount of seed than any sort on the market today. The Wagner's Yellow Pear is far superior in every way, both in bearing qualities and hardiness. It is the best for market and home use, and especially for making preserves and jellies. No mistake can be made in the planting of this variety commer cially as good profits can be realized. Under 2 feet, $75 \mathrm{c}$ each; 2.3 feet, $\$ 1.00$ each; 3.4 feet, $\$ 1.25$ each; over 4 feet, $\$ 1.75$ each.

\section{Deciduous Fruit Trees}

\section{Apples}

3-4 feet, 45c Each; \$4.00 Dozen

4-6 feet, 50c Each; $\$ 5.00$ Dozen

Delicious. A large apple with a surface almost covered with a brilliant dark red blending to golden yellow at the blossoms end. November to April.

Jonathan. Fruit of medium size, rarely large; color, pale yellow, overlaid with red, stripped with carmine. Comes into bearing when young. Season November to January.

N. W. Greening. Fruit medium to large; pretty uniform in size and shape; flesh is tinged with yellow, firm, moderately fine, crisp, rather tender, juicy. Season November to January.

Red Astrachan. Early summer. A beautiful early Russian apple, light and dark red striped and splashed with a bluish bloom.

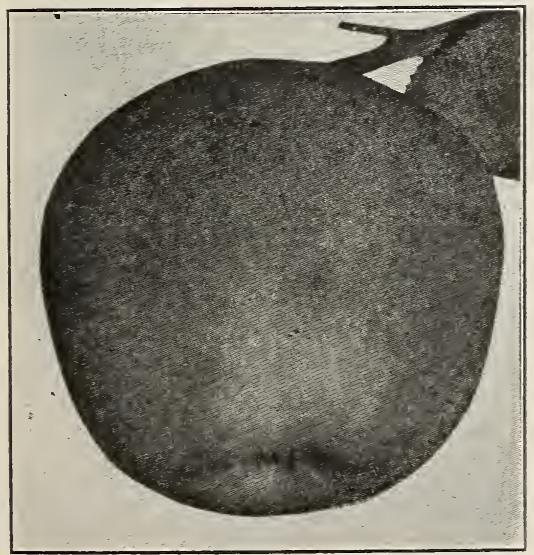

WINTER BANANA APPLE
Red June. Uniform in size and shape deep red over yellow. Comes into bearing early. Season late July to early winter.

White Winter Pearmain. Large, roundish, pale yellow skin with slight blush, many minute brown dots. Flesh yellowish, tender crisp, and juicy.

Winesap. Fruit medium, uniform size and shape. Skin smooth, glossy, bright deep red. Season December to May.

Winter Banana. Fruit large, skin moderately thick, waxy, bright pale yellow and occasionally red cheek.

Yellow Bellflower. Skin smooth, bright pale lemon yellow. This is one of the best varieties grown in California for home and comniercial purposes.

Yellow Newtown Pippin. Smooth greenish. yellow skin with brownish red cheek. December to May.

Grimes Golden.

Gravenstein.

Arkansas Beauty. Rome Beauty.

\section{Crab Apples}

Transcendent. Large golden yellow with red cheek. Fine flavored, hardy and productive, makes good cider.

Hyslop. Fruit medium. Color, yellow rounded with heavy shade of deep crimson, splashes of maroon with heavy blue bloom. It is one of the most desirable for culinary purposes. September to October.

\section{Pears}

3-4 feet, 50c; \$4.00 Dozen 4-6 feet, $\$ 5.50 ; \$ 5.00$ Dozen

Bartlett. Large, bright yellow with red blush. The white, fine grained flesh and excellent quality makes Bartlett the leading commercial variety. Ripens August.

Winter Nelis. Medium size, yellowish. green, dotted russet. Flesh fine grained, rich and sweet with a delicious aromatic flavor. November. In big demand during the holiday season.

Bosc.

Seckel.

Kiefer.

Winter Bartlett. 


\section{Plums}

3-4 feet, $45 c$; 4-6 feet, $50 c$.

Burbank. Large red with lilac bloom; flesh deep yellow, very sweet; commences bearing when 2 years old.

Damson. Fruit small oval shaped. Skin purple; flesh juicy, rather tart and very desirable for making jam.

Hale. A yellow plum, nearly round; flesh yellowish; one of the earliest plums grown in California. Sweet and luscious.

Beauty. Bright red, yellow flesh tinged with red. Exceedingly proliflc; good size and quality.

Green Gage. Rather small, round, surface green, becoming yellowish green. Flesh pale green, melting, juicy, exceedingly sweet and rich; unequaled in flavor.

Kelsey. ... A very large, late, heart shaped plum. Skin mixed yellow and purplish color

Santa Rosa. Fruit large and fine. When ripe a rich deep purple with amber flesh near the stone. Quality and beauty unsurpassed. Our favorite.

Satsuma. Large, dark red; firm, solid, juicy; delicious flavor, very small pit. Ripens early.

Wickson. ..-Tree a hardy and upright grower. Fruit a deep maroon red, firm, a good keeper; flesh dull yellow, meaty and good quality.

Duarte.

Climax.

\section{Prunes}

3-4 feet, $45 \mathrm{c} ; 4-6$ feet, $50 \mathrm{c}$.

French Prune. Medium size, egg shape, violet purple; very sweet and sugary; the most extensively planted for drying.

Italian Prune. A fine late prune, oval, purple; flesh juicy and delicious, parts from the stone; fine for drying.

Hungarian. Very large, dark brownish purple; eating and canning.

Sugar. Earlier, larger and sweeter than French, not quite so good a dryer. Heavy bearer in some localities, not so good in others.

\section{Apricots}

3-4 feet, $45 \mathrm{c}$; 4-6 feet, $50 \mathrm{c}$.

Blenheim. Fruit large and oval, orange color. Flesh deep yellow, rich and juicy.

Early Golden. Small, surface wholly pale orange. Hardy, very productive. Extra early.

Royal. Medium to large fruit, depending upon the thinning out. Skin yellow, shading to orange. Medium early.

Moorpark. Large variety with orange skin shading to deeper orange or brownishred. Flesh bright orange, quite firm and juicy with luscious flavor. A favorite.

Newcastle. Tilton.

\section{Peaches}

\section{3-4 feet, $45 c$; 4-6 feet, $60 c$.}

Strawberry. Extremely early peach. Good variety of the earliest market; white flesh.

Briggs Red May. Fruit large to medium, white skin with rich red cheek, partially free. A good early variety.

Sneed. Medium sized fruit, white flesh. Strong grower. A good peach. Extra early. Freestone.

Alexander. An early peach of good quality medium size, skin greenish-white covered with rich red.
Early Imperial. A heavy grower, fruit large with small pit, skin yellow heavily shaded with dark red.

Early Crawford. A magnificent, large yellow peach of good quality. lts fine size and beauty make it one of the most popular sorts.

Elberta. Large, bright yellow with a beautiful mottled red cheek; flesh yellow; an excellent market variety. Late in July.

J. H. Hale. About the size of Elberta. Ripens about five days earlier. Color yellow and deep carmine blush.

Foster. Large, deep orange color, turning to red in the sun. Flesh is yellow, rich and juicy, of the finest quality. Ripens ahead of Early Crawford.

Lovell. Large, round yellow, very uniform. Flesh yellow, firm and richly flavored. A splendid canning, shipping and drying variety. About ten days later than Muir.

Crosby. Fruit medium size, roundish, slightly flattened; bright red cheek; flesh yellow.

Late Crawford. Large, round, with deeper coloring than Early Crawford.

Muir. Excellent quality; flesh yellow clear through; pit small, one of the most popular for canning and drying. Yellow freestone.

Salway. Fruit large and roundish; deep yellow with a dull red cheek; flesh yellow firm, juicy and rich; one of the very best late peaches.

Levy Late Cling. (Henrietta) Very late yellow. A good sort for the home orchard. Ripens 50 days after Elberta.

Phillips Cling. Medium Sort. Fruit large, round with slight blush on the sunny side; fiam, yellow to the center.

Heath Cling. Late Sort. Very large fruit; skin downy, creamy white, with faint blush flesh greenish white.

George Fourth. (Clure's Strawberry Cling.

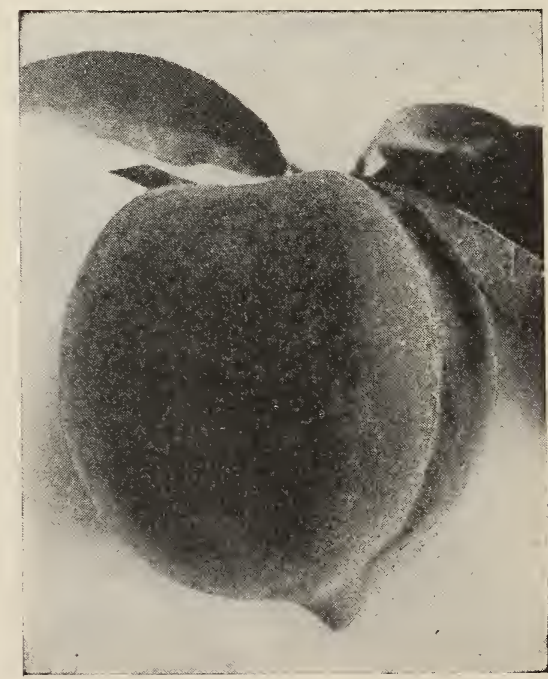

ELBERTA PEACH 


\section{Mulberries}

Russian. Very hardy, vigorous grower, fruit of small size and varies in color from white to black. Largely planted for windbreaks, also in chicken yards for shade; fruit fine for chickens. 3-4 feet, $50 \mathrm{c}$; 5-6 feet,, $75 \mathrm{c}$ each; 6-10 feet, $\$ 1.00$.

Nor de Spain. Called by some the Logan Mulberry as the berries resemble same in every respect, color and flavor, very tart and is excellent for making jams and jellies. Small, 75c; larger, $\$ 1.25$ each.

Teas Weeping Mulberry. Similar to a weeping willow. $\$ 1.00$ to $\$ 5.00$, according to head.

\section{Nectarines}

4-6 feet, each 50c; dozen, $\$ 5.00$ Small trees, each, $40 \mathrm{c}$.

Boston. Large, bright yellow with red cheek, flesh yellow, sweet and pleasant flavor. Freestone.

Stanwick. Large size, flesh white, tender and juicy and delicious, skin greenish white.

New White. Fruit round and large. Free small pit; flesh white, rich and delicious: skin white.

\section{Cherries}

4-6 feet, each $75 \mathrm{c}$; dozen, $\$ 7.00$

Lighter grade, each, $65 \mathrm{c}$; dozen, $\$ 6.00$

Lambert. A very promising cherry of largest size. Flesh red, firm and of unsurpassed quality. June.

Bing. One of the best black cherries in existence. lt is large, firm and delicious. Middle of June.

Napoleon or Royal Anne. Very large; pale yellow with bright red cheek; very firm; juicy and sweet. First of July.

Richmond. Medium size; dark red, melt ing, juicy , sprightly acid flavor. This is one of the most valuable and popular of the acid cherries. Ripens through June.

English Morello. The best sour variety of cherry for Southern California. Medium to large, blackish red; very productive.

Compass. Tree a good grower. Fruit small red. Called either plum or cherry. It does well where other cherries fail.

\section{Persimmons} 4-6 feet, Each, $\$ 1.50$; Dozen, $\$ 15.00$;

2-3 feet, Each, \$1.00; Dozen, $\$ 8.00$

Hachiya. Large, conical, bright red. Flesh yellow; of highest flavor. Finest for Califormia planting. Few seeds. Early ripening.

\section{Quince}

\section{3-4 feet, $50 \mathrm{c}$; 4-6 feet, $60 \mathrm{c}$}

The Quince is becoming more popular each year as new uses are found for it. There is no fruit that can equal it as a filler for salads after being preserved, having a piquancy in taste that is as unusual as it is delightful.

Orange. Large, golden yellow; firm, tender flesh, excellent flavor; strong and thrifty grower; best for preserves.

Pineapple. Large size, smooth and round. It may be eaten as an apple after being thoroughly ripened; will keep indefinitely.

\section{Smyrna Quince}

3-4 feet, 50c; 4-6 feet, $60 c$

Smyrna. The fruit of this superb variety is very large and of a lively, lemon yellow color, tender and delicious when cooked.

Angers. A very hardy and strong grow. ing variety.

Champion. One of the old stand-by va rieties and more grown than any other sort.

\section{Pomegranates}

Pomgranates. Double flowering. Red, white and variegated. The double flowerin varieties are excellent for lawn planting with other shrubbery; blooms the largest part of the summer months. $50 \mathrm{c}$ to $\$ 1.00$.

Wonderful. A recent introduction of great merit. Large, highly colored and attractive. Pulp bright garnet. Abundance of juice and excellent flavor. Valuable for shipping to Eastern markets. October. 3-4 feet, $40 \mathrm{c}$; 4-6 feet, $60 \mathrm{c}$

Large Fruited. Tested by the government lt is the largest fruiting variety grown at this time. Seeds are bright red and good taste, rind thin. A highly recommended variety. $50 \mathrm{c}$ to $75 \mathrm{c}$.

\section{Figs}

3-4 feet, Each 50c; Dozen, $\$ 4.00$; Hundred, $\$ 35.00$

4-6 feet, Each, 50c; Dozen, $\$ 5.00$; Hundred, $\$ 50.00$

Mission, or California Black. The only black fig that is dried commercially in California. Hardy and productive wherever the fig can be grown. Fifteen degrees above zero will not injure the tree when dormant. lt is now grown where thought impossible a few years ago. Strong upright grower and sure cropper. Bears young.

White Adriatic. Large; skin greenishyellow; flesh reddish; tree strong grower and prolific; largely planted in California.

White Genoa. Fruit large, yellow, finegrained; rich flavor. Produces large crops throughout the season until October.

White Pacific. The best of all figs for home use. Medium size; skin thin, yellowish-green; flesh light yellow. Does not crack or sour when ripe. August to November.

Kadota. Sometimes sold as White Endrich, White Pacific, Vardoni, etc. The fruit is a good size, thin white skin and white reddish yellow pulp. Absolutely the sweetest and finest flavored fig known. So sug. ary that it is impossible for it to sour on the tree. Unsurpassed for cooking, canning, eating fresh or served in any manner. No sugar necessary even for preserving. Tree a strong upright grower. Ripens rfom earliest spring till frost. Bears the first year in the nursery.

Celeste. A small variety of amber color. Pulp reddish; slow grower, heavy cropper; good for home consumption. Very sweet and fine for preserves; the hardiest known fig.

Honey or Rose Blanche. Medium to large; roundish, long stalk, brown or white ground; flesh bright red. One of the best varieties grown today, and the sweetest; no mistake will be made in planting this variety as it is a heavy producer and suitable for table and commercial purposes. 


\section{The Nut Fruits}

\section{Walnuts}

Wagner's Giant Black. The best and quickest growing walnut for timber grown at this time. A tree in the nursery row six years after planting measured over two feet in diameter at the base. A representative of the Department of Agriculture from Washington, D. C., after seeing the tree said it was the most extraordinary growth of a walnut or hardwood tree he had ever seen. This statement is one by itself, and enough to convince any man to plant this tree for timber or shade. A good feature of this hybrid is that the seeds will prove true to parentage when planted, which is another good factor to its credit. The nuts resentble English hard shell and have a sweet kernel, of course not as desirable as the English, but is excellent for culinary purposes.

Practical tests of the timber have demonstrated beyond doubt the best of all walnut timber, being tough, close grained, and of fine texture. lt is highly recommended for roadside planting and shade planting, on account of it being a fast grower, and will do well in any aluvium soil and needs little care after being established. If you contemplate the planting of ground for timber we advise the planting of Wagner's Giant Black and you will not be disappointed in the returns. We have a booklet that gives more information about Wagner's Giant. Write for it.

Prices: Under 2 feet, $25 \mathrm{c}$ each; $\$ 2.00$ per dozen; $\$ 12.50$ per hundred; 2.3 feet, $50 \mathrm{c}$ each, $\$ 3.50$ per dozen: $\$ 20.00$ per hundred. We can supply seed of the Wagner Giant Black Walnut, each $\$ 10 \mathrm{c}$; dozen, $75 \mathrm{c}$; hundred, $\$ 4.00$; thousand, $\$ 35.00$.

Seiboldia. An excellent variety for shade planting; good grower, the leaves being three feet long, which makes it excellent for shade on a lawn. Price same as Wagner's Giant.

Placentia (Budden). Commonly known as Placentia Perfection. Still remains the most popular and profitable walnut grown in Southern California. Kernels a re full, whitemeated and are of excellent flavor and qual ity. 6.8 feet, $\$ 1.25$ each. 3.4 feet, $75 \mathrm{c}$ each.

California Black. An exceedingly fast grower, is good for street shade and forest planting. Nuts medium size and sweet, not as highly prized, of course, as the soft shelled varieties. 4-6,75c each; dozen, $\$ 5.00$; hundred, $\$ 40.00$; also $3-4,50 \mathrm{c}$ each; dozen, $\$ 3.50$; hundred, $\$ 20.00$.

English Soft Shell Seedlings. Grown from pedigreed seed of the Santa Barbara, Eureka, Placentia, Franquet and Klondyke. Under 2 feet, same as Wegner Giant; over 2 feet, at $50 \mathrm{c}$ each.

Eureka (Budded). Upright and vigorous grower, clean branches and open growth, slightly rough bark and not subject to sun- burn; recommended as one of the best producers. 6-8 feet, $\$ 1.25$ each; 3.4 feet, $\$ 1.75$ each.

\section{Pecans}

Daisy Seedlings. Our experience has proved that very fine results are obtained from these trees, grown from selected seed off isolated trees in our own orchard, and we highly recommend them for California conditions as they are very hardy and produce constantly very heavy crops of a large delicious nut. We can supply in large or small quantities. Each $35 \mathrm{c}$; dozen, $\$ 3.00$ hundred, $\$ 20.00$.

\section{Almonds}

4-6 feet, 50c; Dozen, $\$ 5.00$

I. X. L. Tree a sturdy, rather upright grover with large leaves; nuts large with, as a rule, single kernels; soft shell.

Nonpariel. Of a weeping style and growth, smaller foliage than the 1 . X. L. An extraor dinary heavy and regular bearer; thin shell.

Drake's Seedling. Nut medium size, roundish: shell soft; blooms late; bears abun dantly; a popular commercial sort.

\section{Vegetable Plants}

\section{Asparagus}

Argenteuil. The favorite in the Paris markets, and exceedingly popular wherever grown in the United States. The stalks grow to an enormous size with tinge of purple, cooks tender, of delicious flavor. Dozen, 35c; hundred, $\$ 1.50$; thousand, $\$ 8.00$.

Palmetto. Standard among the asparagus shippers of California. This strain grows to mammoth proportions and very even in size, which makes it especially popular with shippers. The shoots are a light green, slightly tinted with pink, and are tender to an unusual length. No one will be disappointed with the productiveness and fine edible qualities of Palmetto Asparagus. Dozen, 35c; hundred, $\$ 1.50$; thousand, $\$ 8.00$.

Washington. A new rust resistant variety, was bred up b ythe United States Bureau of Plant Industry co-operating with Massachusetts Agricultural Experiment Station, covering a period of fourteen years. This is a new and excellent variety of asparagus. Dozen, $50 \mathrm{c}$; hundred, $\$ 1.75$ thousand, $\$ 12.50$.

\section{Artichoke}

French Green Globe. The standard of quality. Does not come true from seed. Resembles a rank growing thistle. The pods are cut before they bloom and are cooked and eaten like asparagus. Fine flavor and very profitable when grown for market. It is not a tuber like the Jerusalem Artichoke. 20c each; $\$ 2.00$ per dozen.

\section{Horse Radish}

Horse Radish. Maliner Krren and American. Each, 5c; hundred, $\$ 1.25$; thousand, $\$ 10.00$.

\section{Miscellaneous}

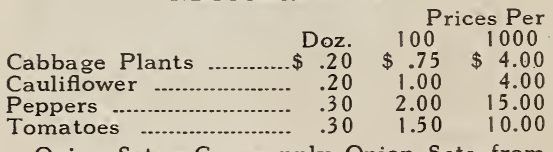

Onion Sets-Can supply Onion Sets from 1 st of October to July 1st. Per lb., 15. 


\section{Ornamental Trees and Shrubs}

\section{Conifers and Coniferous Shrubs}

\section{Cedars}

Cedrus deodara (Himalayan Cedar). A most popular conifer. Silvery blue foliage, pyramidal form; attaining majestic size; beautiful in the youngest specimen. Fast growing and quite resistant. Balled, bushy specimens, 3-4 feet, $\$ 5.00$.

\section{Cypress}

Arizona Cypress. Exceedingly hardy, fast growing, drought resistant. Foliage silvery gray, slender pyramidal form, rapid grower. Makes a good silvery gray hedge, or tall tree with a broad base; more tapering habit than ltalian Cypress. Pots and cans, 8-12 inches, $25 \mathrm{c} ; 2$ feet, $75 \mathrm{c}$; 3 feet, $\$ 1.00 ; 4-5$ feet, $\$ 1.25$ to $\$ 2.00$.

Monterey Cypress. The commonest variety, universally used for hedges and windbreaks. The fastest grower of all. Bright green, and attains majestic size. Perfectly droug ht resistant. Pots and cans, I foot, $20 \mathrm{c} ; 2$ feet, $40 \mathrm{c} ; 4$ feet, $\$ 1.00$. Balled, 4-6 feet, $\$ 1.50$; flats, 8.16 inches, hundred, $\$ 3$

Italian Cypress. Slender, erect, very tall columnar habit, fast growing and hardy. Select compact type and grow as dry as possible after the first year. Plants grown from cuttings have better form and habit. Seedlings, pots and cans, 8-12 inches, 25c; balls or cans, 3 feet, $\$ 1.00 ; 4$ feet, $\$ 1.50$; feet, $\$ 2.25 ; 6$ feet, $\$ 3.00$.

\section{Redwood}

Sequoia ..Sempervirens. Fast upright growing California redwod with tapering trunk and drooping foliage not closely matted. 2 feet, $\$ 1.50 ; 4$ feet, $\$ 3.50$.

\section{Arbor Vitae}

Occidentalis Pyramidalis. Dark freen, slender pyramidal, not dense, but very graceful. Balled, 18 inches to 2 feet, $\$ 2.00$.

Orientalis Aurea Nana. The most wanted arbor vitae. Very dwarf, golden tipped broad ovel shape. Always scarce. Balled, 12 inches, $\$ 1.50$; 15 inches, $\$ 2.00$.

\section{Tamarix}

Tamarix articulata (Evergreen Tamarix, or Athel). Exceedingly fast growing evergreen tree. Very hardy, thriving in most extreme heat and drought and standing considerable frost. Upright trees, drooping branches, fine needle-like foliage, soft gray color. A beautiful tree and a good windbreak. Grows readily from unrooted cuttings. 1-foot cuttings, $25 \mathrm{c}$ each; $\$ 12.00$ per 100. Cans, 4 feet, $\$ 1.00$.

\section{Pines}

Monterey Pine-Our native pine of California; very rapid grower. $2-3$ feet, $\$ 1.00$.

\section{Landscape Department}

We are establishing a Landscape Department in our Nursery and endeavor to have available at all times the services of a first-class Landscape Architect and Designer and would be pleased to have referred to us by our customers any of their problems in connection with the lining out and planing of their places, new and old. For a nominal charge, where desired, if the size of lot and description of the house is given, we will draw up a sketch showing the most desirable manner of landscaping the home grounds.

There is nothing that lends more to the attractive appearance of a new place than the landscape plan and on the other hand unless carried out to conform with the architectural design there is nothing that ruins its appearance more.

We endeavor to have on hand at all times choice selections of ornamentals that can be appropriately used with all the different types of architectural designs and we take pleasure in quoting on the list of the wants of our customers in this line. 


\section{Broad Leaved Evergreen Trees and Shrubs}

\section{Abelia}

Abelia (grandiflora). Graceful spreading shrub, growing to 5 or 6 feet height in about four years, entirely hardy in all respects; small, sharp pointed glossy foliage. Loose clusters of small white bell-shaped flowers bloming from June to October. General habit of Bridal Wreath, but quite different flower. One of the very best. Pots and cans, 18 inches, $75 \mathrm{c}$; balled, 2.3 feet, $\$ 1.50$.

\section{Acacia}

Baileyana. The favorite flowering acacia, deep silvery blue fernlike foliage, with a wealth of fluffy canary yellow flowers in February and March. Cery fast, upright, eventually compact shape, 25 feet. Usually a short lived tree. Stock very scarce at present. Pots or cans, 1-2 feet, $75 \mathrm{c}$.

Melanoxylon (Black Acacia). The commonest street tree in Southern California. Erect, compact, 50 to 60 feet, foliage dense, long flat leaves, flowers dull cream, inconspicuous. March or April. Exceedingly fast and hardy. Cans $3-4$ feet, $75 \mathrm{c}$; 6 feet, $\$ 1.00$.

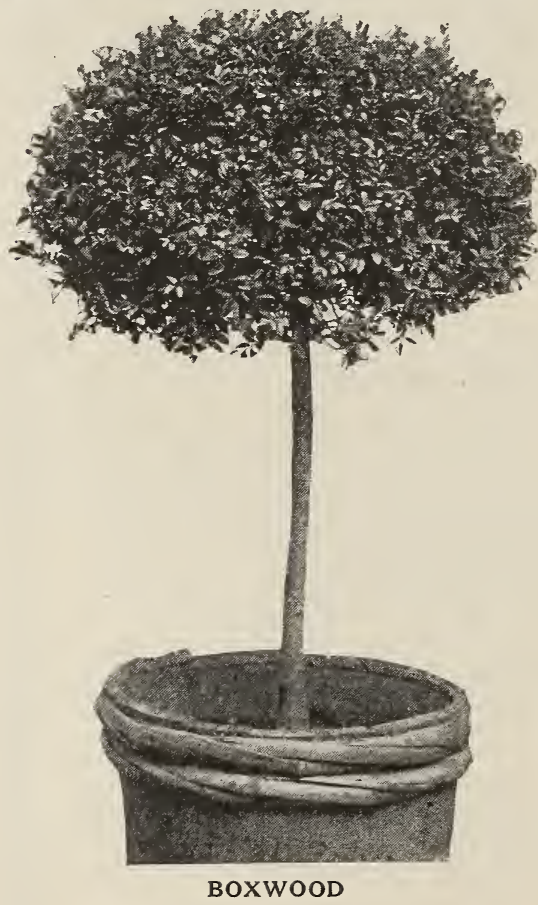

\section{Boxwood}

Boxwood japonica (Japanese Boxwood). Leaves round, larger than other boxwood, and of a glossier, lighter, yellower green Faster grower than English Box, not so dense, requires more trimming, more likely to be discolored by frost and sun in winter. Flats of $100, \$ 5.00$. Balled, bushy, 16 inches, \$1.25; trimmed, $18-24$ inches, $\$ 2.50$ to $\$ 5.00$.

\section{Coprosma}

Coprosma baueri. Low growing shrub that can be trained to a pillar. The rounded green leaves are very glossy and beautiful. Flowers inconspicuous, but followed by clusters of showy yellow berries. Cans, 1-2 feet, $60 \mathrm{c}$.

\section{Cotoneaster}

Cotoneaster horizontalis. Branches very low, spreading close to ground. Foliage small, turning red in winter. Flowers light pink. Bears brilliant red berries in greatest profusion, remaining through the winter. Cans, each, 18 inches, $75 \mathrm{c}$.

Cotoneaster franchetti. Spreading drooping shrub, 5 to 6 feet, medium to large leaves, dark green, with bronzy-silver reverse. Pinkish-white flowers followed by well scattered, orange-red brries of good size. Cans, 18 inches, $75 \mathrm{c}$; balled, 2 feet, $\$ 1.50$.

Cotoneasted panosa. Probably the most valuable of all. Fast grower, 3 to 4 feet in one year , attaining 8 feet; upright but graceful, open growth. Foliage covered with short silvery hairs, very pleasing. Small white flowers in clusters followed by brilliant crimson berries at every leaf joint. Cans, 18 inches, $85 \mathrm{c}$; balled, 2 feet, $\$ 1.00$; 3 feet, $\$ 1.50$.

\section{Diosma}

Diosma alba (Breath of Heaven). Fine leaved, heather-like foliage, light green; dense round, compast growth; rather slow and dwarf. Dainty white flowers. Fragrant aromatic scent. Susceptible to heavy frost. Combines well with Ericas. Balled, bush, $12-15$ inches, $\$ 1.25$.

\section{Erica}

Erica (Heath or Heather). A group of beautiful fine needled shrubs with dainty small cup or tubeshaped flowers. Many of them are very hardy, all are beautiful. Fine for grouping near porches or entrances, very effective for decoration.

Erica Felix Faure. A group of dwarf ericas, very similar with light green compact foliage and long tubular pink flowers, tipped white, the most beautiful of all, blossoming from December to May. Height 2 to 3 feet. Balled, 10-18 inches, \$1.25.

Erica Mediterranea. One of the fastest and hardiest; very dark green, thick and bushy, growing 6-7 feet. Dark lavendar flowers, March to June. Very drought resistant. Balled, 10-12 inches, $\$ 1.00$.

Erica melanthera. The best of all. Fast grower, 6-7 feet; fine, delicate foliage, but exceptionally hardy, standing sun, drought and frost except while very voung. Blooms in November or December, delicate pinkish with black eye. Balled, is inches, \$1.00; 20 inches, $\$ 1.25 ; 4$ feet, $\$ 2.50$.

\section{Eugenia}

Eugenia myrtifolia. Tall erect shrub growth compact. New leaves are ruddy, changing to dark glossy green. Flowers creamy, edible violet berries. Used for hedges or can be pruned into pyramids. $2-3$ feet, \$1.50. 


\section{Arbutus}

Arbutus unedo. Bushy, spreading shrub with upright branches, stiff bright green leaves with red tinge: very ornamental. Fruit resembles a strawberry. One of our finest shrubs. Balled, 2 feet, $\$ 1.75 ; 21,2-3$ feet, $\$ 2.50$.

\section{Eucalyptus}

Eucalyptus globulus (Blue Gum). The commonest of all for street trees, windbreaks and timber. One of the fastest growing trees in the world. Too well known to need description. Pots and cans, l foot, $20 \mathrm{c} ; 2-3$ feet, $35 \mathrm{c}$ each; $3-4$ feet, $40 \mathrm{c}$.

Eucalyptus Ficifolia (Scarlet Flowered Gum). The most beautiful of all, dark glossy leaves, compact bushy tree about 20 to 25 feet; great clusters of brilliant blos. some ranging from pink through all the reds and scarlets to crimson. It is impossible to tell the exact color before they bloom. Rather tender as to frost, especially while young. Pots and cans, 2 feet, $\$ 1.00 ; 3$ feet, $\$ 1.50$.

\section{Genista}

Genista scoparius (Scotch Broom). The true Scotch. Both Canariensis and Spanish are often called Scotch. Slender, erect fourangled branches, very few leaves, large yellow flowers, plentiful, but well scattered. Bushy, upright habit, $6-8$ feet; cans, 2-3 feet, $75 \mathrm{c}$.

\section{Lantana}

Lantana farfarden. Orange and yellow flowers. Requires some frost protection. Potted, 60c.

\section{Lauristinus}

Lauristinus grandiflora. Large glossy leaves and large clusters of white flowers freely borne in winter and early spring. One of the finest evergreen shrubs and herge plants. Potted, 1 foot, 50c; $1-2$ feet, $75 \mathrm{c} ; 2-3$ feet, $\$ 1.00$.

\section{Leptospermum}

Leptospermum laevigatum (Australian Tea Tree). Graceful arching habit, oval grayish foliage. Covered in April and May with white flowers size of a dime. Very fast and hardy. Balled, \$1.00. Privet, cans, 15.18 inches, $75 \mathrm{c}$.

\section{Ligustrum}

Ligistrum napalense (Privet). Makes a very compact dark green hedge if frequently pruned; better color in summer than in winter. Loose branching growth. Blossoms very freely in May and June. May be trimmed to beautiful, formal specimens. Flats of $100,6-12$ inches, $\$ 2.50$ pots and cans, 8-10 inches, $15 \mathrm{c} ; 12.15$ inches, $25 \mathrm{c} ; 18.24$ inches, $50 \mathrm{c}$.

\section{Mexican Orange}

Choisya ternata (Mexican Orange). Bril liant green bushy and spreading habit, growing 5 to 6 feet in three or four years. Flower clusters at ends of branches, white and grafrant. February to June. Cans, 10 inches, $50 \mathrm{c}$.

\section{Myrtle}

Myrtus microphylla (Myrtle). Leaves very small and set closely together. A very neat compact shrub. Balled, 12 inches, $\$ 1.00$.

\section{Pittosporum}

Pittosporum eugenoides. Erect symmet rical growth; long, narrow, yellowish green leaves; slender black twigs. More success ful in cool localities. Makes a good hedge and fine trimmed specimen. Cans, slender, 1-11/2 feet, $65 \mathrm{c}$; balled, 3 feet, $\$ 1.00$

Pittosporum undulatum. The largest and fastest growing species, large leaves, mediun green in color; glossy, attractive, slightly curved margins. Bush shrub eventually size of an orange tree. Fragrant inconspicuous flowers. Injured somewhat by frost, but recovers quickly. Cans, $18-24$ inches, $85 \mathrm{c}$; balled, $3 \mathrm{ft}$., $\$ 2.00$.

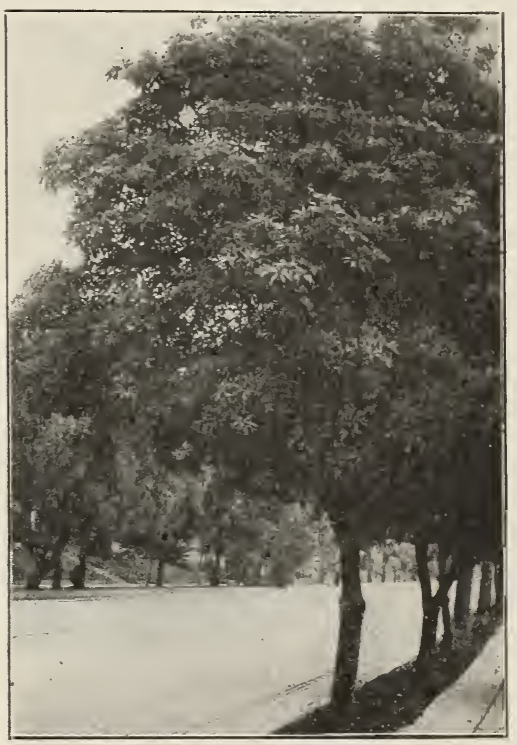

PITTOSPORUM UNDULATUM

\section{Pyracantha}

Pyracantha augustifolia. Evergreen Hawthorne. Long branches of spreading pros. trate habit, bearing clusters of white flowers. Bright orange berries throughout winter. Potted, 1-2 feet, 75c. Balled, 2-3 feet, $\$ 2.00 ; 3.4$ feet, $\$ 3.00$.

Pyracantha yunnanensis. Dark rich green foliage, low spreading habit, some branches almost prostrate; brilliant scarlet berries, almost coral. Holds berries late in season. Potted, 1-2 feet, $75 \mathrm{c}$. Balled, 3-4 feet, $\$ 3.00$.

\section{Rubber Tree}

Ficus Elastica (Rubber Tree). Usually grown as a pot plant, but makes a tree in reasonably frost-free locations. Leaves larger than macrophylla, glistening green of a lighter color, and does not stand the hot sun quite as well. Tree rounder and not quite so large. Potted plants suitable for window use or for planting, $\$ 3.00$ to $\$ 5.00$. 


\section{Deciduous Shrubs and Trees}

\section{Deutzia}

A group of extremely beautiful and free bloming shrubs. Very hardy and fast growing. 3 feet, $60 \mathrm{c}$; 4 feet, $75 \mathrm{c}$; 6 feet, $\$ 1.25$; 8-10 feet, $\$ 2.00$.

\section{Forsythia}

Golden Bell. One of the earliest blooming Spray Golden Bell. One of the earliest shrubs. February. Golden yellow on bare branches, very showy, hardy; height 6 feet. 4 feet, $75 \mathrm{c}$; 5 . feet, $90 \mathrm{c}$.

\section{Hibiscus}

Very showy and hardy. Cans, 2 feet, $\$ 1.00 ; 4$ feet, $\$ 2.00$.

\section{Lilac}

Common purple. Rather slow in blooming. 18 inches, $60 \mathrm{c} ; 24$ inches, $75 \mathrm{c}$.

\section{Mulberry}

Teas Weeping Mulberry. Similar to a weeping willow. Foliage remarkably bright green, and very dence. Grafted on 8 or 9 feet straigh trunks, can be trained to form a natural, self-supporting arbor. Smaller trees give the effect of a living fountain. From $\$ 1.00$ to $\$ 5.00$, according to head.

\section{Poplars}

Carolina Poplar. A hybrid of cotton wood; more regular form and without seed or cotton. Makes a large tree quickly, but is not long lived. 3 feet, $25 \mathrm{c} ; 4$ feet, $50 \mathrm{c}$; 7-8 feet, $\$ 1.25$.

Lombardy Poplar. The slender, erect columnar poplar often seen along roadsides or driveways. Grows 5 to 6 feet a year, becoming 75 feet high. Requires little space, and is perhaps the hardiest of our poplars; stands drought well. 5 feet, $50 \mathrm{c} ; 6$ feet, $75 \mathrm{c} ; 7.8$ feet, $\$ 1.00$.

Chinest Poplar. Very different foliage and very decorative. 4 feet, $\$ 1.00$.

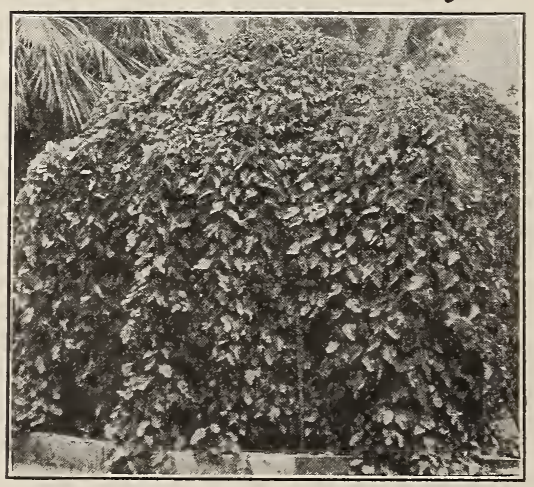

TEAS WEEPING MULBERRY

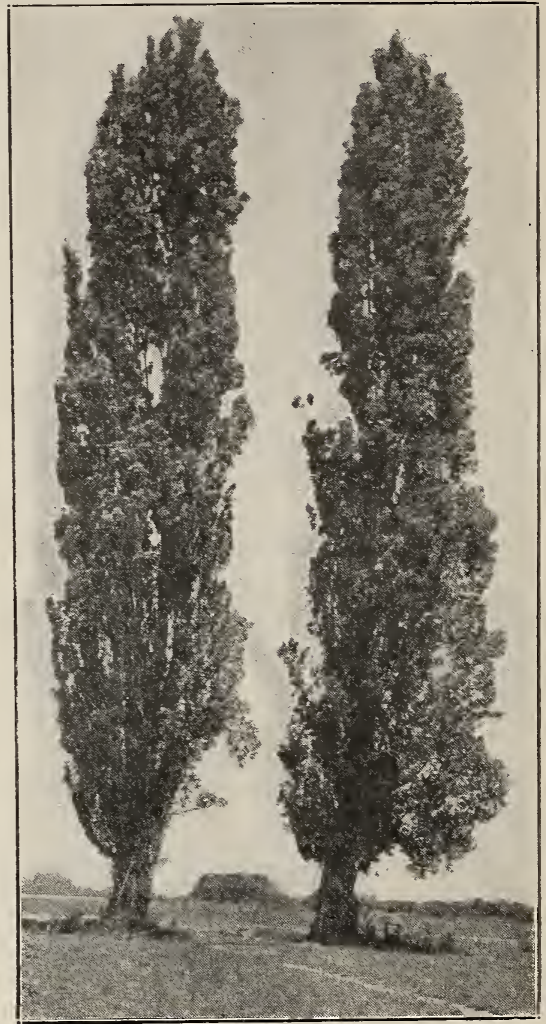

LOMBARDY POPLAR

\section{Snowberry}

Sprays and clusters of milk-white berries the size of small marbles cover the 2 to 3 foot bushes in early fall, September to November. Spreading, bushy growth; very attractive. 2 feet, $50 \mathrm{c} ; 3$ feet, $75 \mathrm{c}$.

\section{Spirea}

Van Houteli. Late blooming, April or May. Flat, single white flowers making the entire bush into a huge snowball; rounded leaves with scalloped edges. 2 feet, $50 \mathrm{c}$; 5 feet, 65c; 4 feet, 85c; 5 feet, \$1.25.

\section{Umbrella Tree}

Texas Umbrella. The heavy evenly branched kind. 4 feet, $75 \mathrm{c}$; 5 feet, $\$ 1.00$; 6 feet, $\$ 1.50 ; 7-8$ feet, $\$ 2.00$.

\section{Flowing Pomegranate}

Flowering Pomegranate. Bright glossy foliage, double curled, brilliant flowers. 2 feet, $\$ ! .00$. 


\section{Annual and Perrennial Flowering Plants}

In Pots, Each, 10c; Dozen, $\$ 1.00$ In Flats, 35c per Dozen

Annuals

Agathaea
Asters
Calendula
Centaurea

$$
\begin{aligned}
& \text { Lobelia } \\
& \text { Marigold } \\
& \text { Stocks } \\
& \text { Zinnia } \\
& \text { Petunia }
\end{aligned}
$$

Perennials

$\begin{array}{ll}\text { Coreopsis } & \text { Pansy } \\ \text { Delphinium } & \text { Penstemon } \\ \text { Dianthus } & \text { Salvia } \\ \text { Fox Glove } & \text { Shasta Daisy } \\ \text { Gaillardia } & \text { Snapdragon } \\ \text { Gerbera } & \text { Verbena } \\ \text { Gypsophila } & \text { Viola }\end{array}$

\section{Selected List of Flower Seeds 10c Per Packet}

\section{Annuals}

Asters. American branching; variety of colors; $1 \frac{1 / 2}{2}$ feet high; full flowers.

California Poppy. Orange; native California flower; I feet high.

Calliopsis. Combination of brown and yellow, daisy like flower 2 feet high.

Centaurea. Blue; common corn flower; 2 feet high.

Centaurea Imperialis. All colors; 2 feet high.

Chrysanthemum. Painted daisy, white, yellow, Crimson; 2 feet.

Cosmos. Crimson, rose, white and mixed; large flowering.

Gypsophila. Pure white; small flower; used for mixing with other flowers. Height, $11 / 2$ feet.

Larkspur. Pink, blue, white; 2 feet high.

Marigold. (African Orange Ball.) Perfect ball of rich golden orange.

French Dwarf. Dark brown; 1-2 feet high.

Mignonette. Yellow, red and white; fragrant; 1-2 feet high.

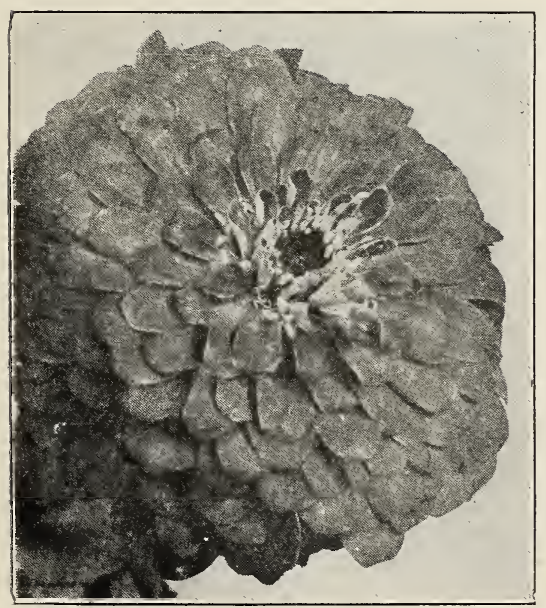

Giant Zinnia
Nasturtium. Tall and dwarf. Golden bronze, yellow and crimson; dwarf, I foot; tall, 6 feet.

Sweet Peas. Spencer Giant; all colors; climbing. Per Packet, $15 \mathrm{c}$.

Stocks. Mixed colors; double and single flowers; 2 feet high. feet.

Zinnia. Mixed colors; hardy; height, 3

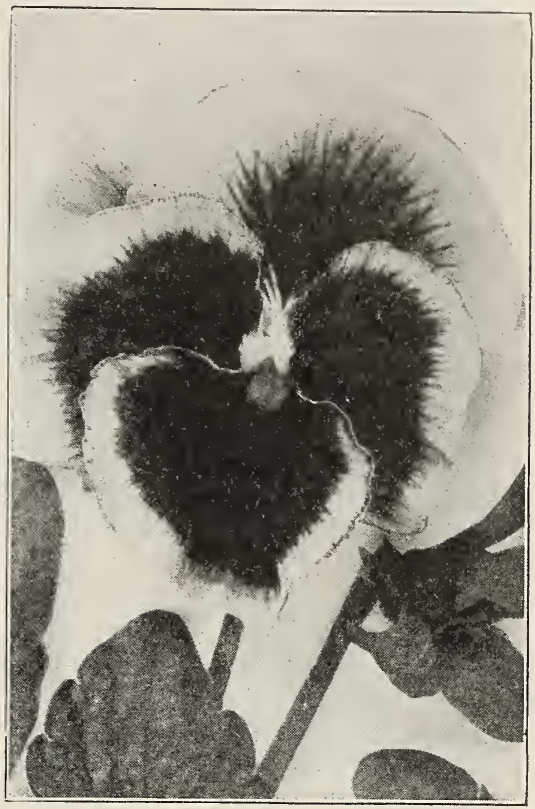

Giant Mastadon Pansy

\section{Perennials}

Autirrhinum. Old fashioned snapdragon, flowering the first year from seed; variety of colors. Height, 1-3 feet.

Campanula. Bell flowers, Canterbury bells, blue, rose and white.

Carnation. Single and double; red, white and pink; height, 1-2 feet.

Delphinium. Perennial larkspur; blue: height, 3 feet.

Hollyhock. Crimson, pink, white and yellow; height, 5 feet.

Pansies. Giant flowering and bedding; all colors.

Petunia. Single and double showy flowers; variety of colors; I foot high.

Phlox. Variety of colors; height, 2 feet.

Verbena. Pink, purple, and scarlet; bedding flower; height, I foot.

Viola. Purple and yellow; resembles the pansy; for bedding purposes.

\section{Lawn Grass Seed}

Blue Grass, pound, $60 \mathrm{c} ; 10$ pounds, $\$ 5.50$

Clover, pound $90 \mathrm{c} ; 10$ pounds, $\$ 8.50$.

Mixed Lawn Seed, pound, 75c; 10 pounds, $\$ 7.00$. 


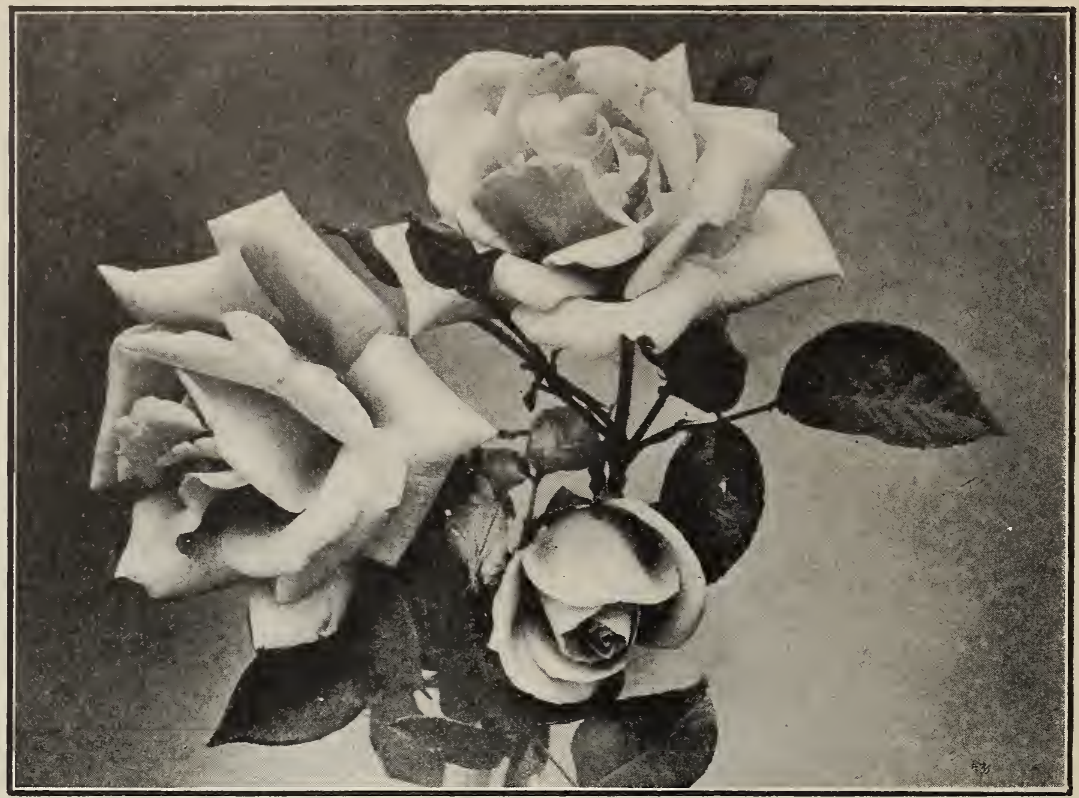

Miss Lolita Armour

\section{Roses}

There is nothing so desirable in a garden as a collection of fine roses, and there is no plant sells so readily, so in ordering please name a second choice if you have one as we do not have our complete list here, due to lack of space.

We can supply some very nice tree roses in two colors at $\$ 4.00$ each.

\section{Choice Roses for the Rose Garden}

Angelus. A new white rose, very free bloomer and beautiful buds. Each, 75c.

Golden Ophelia. A golden yellow, unsurpassed in garden roses. Each, $75 \mathrm{c}$.

Louise Catherine Breslau. Peculiar shade of salmon buff over yellow; unusual. Each, $75 \mathrm{c}$.

Los Angeles. Long stems, beautiful buds, combination of pink and amber over yellow. Each, 75c.

Lolita Armour. Brilliant combination of corral-red and copper-red, over an orange flame color. Each, $75 \mathrm{c}$.

General McArthur. Dark red, splendid shape, and color, almost ever-bloming. Each, 50c.

Hadley. Rich velvety crimson, beautiful buds. Each, 50c.

George Ahrends. The growth and makeup of the plants is superb, while the delicate pink color is unapproachable. Each, $50 \mathrm{c}$.

Marechel Neil. The most famous and most widely known rose in California. The flowers are a wonderful shade of deep yellow. Each, $75 \mathrm{c}$.
GENERAL COLLECTION

Each, 50c; \$5.00 Per Dozen

American Beauty-Red.

Constance--Yellow.

Lady Hillingdon-Yellow.

Mama Cochet-Pink.

Columbia-Pink.

Ophelia-Salmon.

Ulrich Brunner-Crimson.

Hoosier Beauty-Red.

Cecil Brunner-Pink Baby Rose.

Radiance-Dark Pink.

White Maman Cochet-White.

Molly Sharman Crawford-White.

\section{Climbing Roses}

Belle of Portugal. New, strong, vigorous buds of beautiful dawn pink. Each, $\$ 1.00$.

General McArthur. As good as the bush dark red. Each, 50c.

Cecil Brunner. One of the best of all climbing baby roses; salmon pink blossoms. Each, 50c.

Dorothy Perkins. Rambler twye; flowers very double bright pink. Each, $50 \mathrm{c}$.

Cherokee. White, pink and red; single blossoms. Each, 50c.

Climbing Kaiserin. Lovely white blossoms; perfect form. Each, $50 \mathrm{c}$. 


\section{TRADE DISCOUNTS ON BULBS, ETC.}

GLADIOLAS AT $\$ 1.75$ PER 100

America, Bright Red, Chicago White, Faust, Gen. Joffre, Glory of Holland, Halley, Independence, Le Marshal Foch, Los Gatos, Mrs. Francis King, Mrs. Frank Pendleton, Prince of Wales, Peace, Panama, Princepine, War, Klondike, Wagner mixture named Glads, Wagner mixture select colored Primulinus, separate colored Primulinus.

\section{GLADIOLAS AT $\$ 2.35$ PER 100}

Alice Teplady, Golden West, Gretchen Zang, Herada, Ida Van, Golden King, Lily White, Louise, Mrs. Dr. Norton, Mrs. Watt, Niagara, Princepine, Scarlet Princeps, Schwaben, Scarlano, Virginia, Willbrink, Wolverine, Yellow Hammer, Martha Washington, Autumn Queen, Black Pansy, Baby Glads, Bride and Blushing Bride.

\section{GLADIOLAS AT $\$ 3.00$ PER 100}

Butterfly, Chateau Thiery, E. J. Shaylor, Helen Franklin, Baby Glad Ackerman.

\section{GLADIOLAS AT $\$ 5.00$ PER 100}

Golden Measure, Roen Van Kennemerland, Mary Pickford, Pythia, B. L. Smith, Myrtle, Anna Ebereus.

\section{DAHLIAS AND POMPOMS IN SMALL LOTS ONE-} HALF OFF THE DOZEN PRICE

Decorative-Peony and Show type, mixed, $\$ 4.00$ per 100 . Separate shades, $\$ 5.00$ per 100 , numbered sorts, per catalogue description, $\$ 10.00$ per 100 .

Pompoms-Mixed, all sorts, $\$ 4.00$ per 100 . Separate colors or shades, $\$ 5.00$ per 100 . Numbered or described sorts, $\$ 7.00$ per 100 . Single or Cosmo Dahlia, mixed, $\$ 3.00$ per 100 . Separate colors or shades, $\$ 4.00$ per 100 . Described or numbered, $\$ 6.00$ per 100 .

TUBEROSES, all sorts, single or double. $\$ \$ 3.00$ per 100 .

FREESIA PURITY, 75c per 10,0 .

ANTHOLYZA or Orange Watsonia, large bulbs. $\$ 5.00$ per 100 .

SHOOTING STAR, 75c per 100. 
CHUFACE, $50 \mathrm{c}$ per quart.

STAR OF BETHLEHEM (Black Eyed Susan), $\$ 4.00$ per 100 .

MONTEBRETIA, $\$ 2.75$ per 100 .

SPARAXIS, mixed colors, $\$ 2.00$ per 100 .

WATSONIA, all colors, mixed, $\$ 2.00$ per 100 .

WATSONIA, separate colors, $\$ 4.00$ per 100 .

RUNUNCULUS, mixed, $\$ 2.00$ per 100 .

RUNUNCULUS, separate colors, $\$ 3.50$ per 100 .

CANNAS, all sorts, listed under $\$ 1.00$ dozen, at $\$ 2.00$ per hundred; all listed over $\$ 1.00$ per dozen, at $\$ 4.00$ per 100 . Our assortment is very good.

HYACINTHS, $\$ 5.00$ per 100 .

GRAPE HYACINTH, $\$ 1.25$ per 100 .

GERMAN IRIS, common, blue and white and lavender, $\$ 2.50$ per 100 ; Lohengen and Hermosa, $\$ 3.50$ per 100 .

SPANISH IRIS, Imperator and Calumus, Thunderbolt, $\$ 4.00$ hundred.

SPANISH IRIS, mixed, $\$ 4.00$ per 100 .

SIBERIAN IRIS, or Purple Stylosus, $\$ 6.00$ hundred.

CHINESE LILY, yellow, paper white. Solel d'Or and unnamed Jonquils, $\$ 3.50$ per 100 .

AMARYLLIS BELLADONNA, $\$ 7.00$ per 100 .

TO THE TRADE-We herewith present our retail mail order catalogue of Bulbs for your consideration. The Bulbs we use in filling our mail orders, naturally are the smaller sizes.

We retain the larges sizes for our counter trade and dealers, hence the discounts and prices quoted above refer to the larger sizes as a rule. Thanking you for careful consideration of our quotations befor placing your order elsewhere, we beg to remain yours sincerely,

\section{WAGNER NURSERIES}

PASADENA, CALIFORNIA

1350 North Foothill Boulevard

P. O. Box 56, Lamanda Park 


\section{Vegetable Seeds}

\section{Asparagus}

Argenteuil. An excellent variety for the the canner and early shipper. It is prolific and stands shipping. Its purple tinge is at ractive. Packet, $10 \mathrm{c}$; oz., $20 \mathrm{c}$; $1 / 4$ lb., $50 \mathrm{c}$. lb., $\$ 1.50$ postpaid.

Palmetto. A popular variety for the home garden. The sprouts are green and delicious flavor. Pkt., 10c; oz., 20c; 1 / lb. $45 \mathrm{c} ; 1$ lb., $\$ 1.25$.

\section{Artichokes}

Large Green Globe. The favorite garden variety. Pkt., 10c; oz., 20c; $1 / 4$ lb., $\$ 4.00$. 1 lb., $\$ 12.00$

\section{Beans}

Fordhook Bush Lima. Vigorous grower splendid variety. Pkt., 10c; 1/2 lb., 20c; 1 lb., $40 \mathrm{c}$.

Monstrous Bush Lima. Extra large in size for home or market garden. Pkt., $15 \mathrm{c}$ $1 / 2$ lb., 35c; 1 lb., 60c.

Burpees Bush Lima. Pkt., 10c; 1/2 lb., $20 \mathrm{c} ;$ i lb., $35 \mathrm{c}$.

Giant Pole Lima. The largest podded of all Jole limas; vigorous grower, fine flavor. Pkt., 15c; 1/2 lb., 30c; 1 lb., 55c.

Burpees Stringless Green Pod. It is one of the greatest green pod beans to date very tender, without strings; of the highest and best flavor. Pkt., 10c; 1/2 lb., 20c; lb., $40 \mathrm{c}$.

Improved Golden Wax. Strong grower; prolific; a superior bush wax bean; popular for market or garden. Pkt., 10c; $1 / 2$ lb., $20 \mathrm{c}$; 1 lb., $35 \mathrm{c}$.

Improved Prolific Black Wax. In every respect first-class; very early and continues long in bearing; immensely productive. Pkt., $10 \mathrm{c} ; 1 / 2$ lb., $20 \mathrm{c}$; 1 lb., $35 \mathrm{c}$.

Ventura Wonder Wax. A stocky variety of bush. Bean bearing large, long, flat yellow pods, containing white seed with a fine Havor. Pkt., 10c; $1 / 2$ lb., 20c; 1 lb., $35 \mathrm{c}$.

White Kentucky Wonder. A very popular type of Kentucky wonder. Is two weeks earlier than any other type of Kentucky bean. The pods average from eight o ten inches in length. Pkt., 10c; 1/2 lb., 20c; 1 lb., $40 \mathrm{c}$.

Asparagus or Yard Long. Very fine and tender; entire absence of strings; should be grown in every home garden. Pkt., 10c; $1 / 2$ lb., $75 \mathrm{c}$; I lb.; $\$ 1.50$.

Kentucky Wonder Brown. Very early and enormously productive; long been a favorite. Pkt., 10c; 1/2 lb., 20c; 1 lb., 35c.

White Creaseback. An extremely early pole bean; very prolific and an excellent shipper. Pkt., 10c; 1/2 lb., 20c; 1 lb., 35c.

Scarlet Runner. Ornamental and useful; beans excellent quality shelled or dry. Pkt., $10 \mathrm{c} ; 1 / 2 \mathrm{lb}, 20 \mathrm{c} ; 1$ lb., 35c.

\section{Beets}

Crosby's Egyptian. A medium sized beet, very early and small top. Smooth, deep crimson flesh; sweet and tender. Pkt., 10c; oz., 15c; $1 / 4$ lb., $35 \mathrm{c}$; 1 lb., \$1.00.

Detroit Dark Red. One of the best beets for market or home garden. Color, dark red. The root is of medium size, globular or nearly round, very smooth. Pkt., 10c; oz., 20c; $1 / 4$ lb., $45 \mathrm{c}$; 1 lb., \$1.25.

Extra Early Egyptian. Very early; dark blood color; flat shape. Pkt., 10c; oz., 15c; $1 / 4$ lb., $35 \mathrm{c}$; 1 lb., $\$ 1.00$

\section{Swiss Chard or Silver}

For leaf stalks and leaves as greens. Cut often as new stalks will be produced. Pkt., $10 \mathrm{c}$; oz., 15c; $1 / 4$ lb., 35c; i lb., $\$ 1.00$.

\section{Brussels Sprouts}

Half Dwarf Paris Market. A half dwarf sort, bearing fine crops of round, hard sprouts of the finest quality.

\section{Cabbage}

Early Winigstadt. Sure to head, hardy, a good shipper and very early. Pkt., 10c; oz., 35c; 1/4 lb., \$1.20; 1 lb., \$3.50.

Early York. Solid pointed heads; standard English sorts. Pkt., 10c; oz., 35c; 1/4 lb., $\$ 1.20 ; 1$ lb., $\$ 3.50$.

Cannon Ball Cabbage. This is an early round-headed type, producing a heavy crop of solid, compact nature, and excellent quality. It is unsurpassed. It can be placed on the market as early as any other cabbage. We recommend this variety highly. Pkt., 10c; oz., 35c; $1 / 4$ lb., $\$ 1.65$; 1 lb., $\$ 3.50$.

Copenhagen Market. One of the most popular round-headed cabbages with market gardeners. One of the best. The heads are round, extremely solid, and exceptionally good quality. Pkt., 10c; oz., 40c; $1 / \frac{1 b}{\mathrm{l}}$., $\$ 1.35 ; 1$ lb., $\$ 4.00$

Early and Late Flat Dutch. Very good keeper, compact growing. Pkt., 10c; oz., $35 \mathrm{c} ; 1 / 4$ lb., $\$ 1.20 ; 1$ lb., $\$ 3.50$.

\section{Carrots}

Improved Denver Half Long. A first-class carrot for all soils; in form midway between Long Orange and Short Horn. Of a rich, dark orange color, very smooth and handsome, 20 to 30 tons per acre is not an unusual crop. Pkt., 10c; oz., 20c; $1 / 4$ lb., $45 \mathrm{c}$; 1 lb., \$1.25.

Oxheart. A short carrot, especially desirable for heavy soils; especially fine for table use. Pkt., 10c; oz., 20c; 1/4 lb., 45c; 1 lb., \$1.25.

Improved Long Orange. Roots long, tapering to a point; color, deep orange. Suitable for market gardners and for planting commercially. Pkt., 10c; oz., 20c; $1 / 4$ lb., $45 \mathrm{c} ; 1$ lb., $\$ 1.25$.

Early Chantenay. The best early carrot grown for market gardners; fine grained and sugary. Pkt., 10c; oz., 20c; 1/4 lb., $45 \mathrm{c} ; 1$ lb., $\$ 1.25$.

\section{Cauliflower}

Early Snowball. A snow-white cauliflower. Leaves have a tendency to overlap at the top. In this way, it protects from injury, exposure to frost, rain or heat. Pkt., $25 \mathrm{c}$; $1 / 4$ oz., $\$ 1.00 ; 1$ oz., $\$ 3.50 ; 1 / 4$ lb., $\$ 10.00$.

Early Pearl. Should be sown from May 1 st to June 25 th. The plants are ready to be set out in from seven to ten weeks. It is large, white and very meaty; is self branching as it is well covered and not necessary to tie up. Pkt., 10c; 1/4 oz., $\$ 1.00 ; 1$ oz., $\$ 3.50 ; 1 / 4$ lb., $\$ 10.00$.

Late Pearl Cauliflower. Attains a height of three to four feet. This is the variety that has made California Cauliflower famous. Pkt., 25c; $1 / 4$ oz., \$1.00; 1 oz., \$3.50; $1 / 4$ lb., $\$ 10.00$.

Half Early Pearl. Seed should be sown from May 25 th to July 15 th. Plants should be ready to set out in from seven to ten weeks or as soon as they have reached the proper size. Pkt., 25c; 1/4 oz., \$1.00; 1 oz., $\$ 3.50 ; 1 / 4$ lb., $\$ 10.00$. 


\section{Celery}

Golden Self-Blanching. A thrifty variety grows 18 to 22 inches in height, stocky, heavy, solid and splendid shipper. Pkt. $15 \mathrm{c}$; oz., $80 \mathrm{c}$; $1 / 4 \mathrm{lb}$., $\$ 2.65$; 1 lb., $\$ 8.00$.

Easy Blanching. Grows rather dwarf and compact; foliage light green tinged with yellow. 1t blanches more easily than any other variety. Pkt., 10c; oz., 40c; 1/4 lb., $\$ 1.35 ; 1$ lb., $\$ 4.00$.

Golden Self-Blanching. French stock; mild but characteristically flavored. Pkt., $15 \mathrm{c} ;$ oz., $\$ 2.00 ; 1 / 4$ lb., $\$ 6.00 ; 1$ lb., $\$ 20.00$.

\section{Corn}

Adams Extra Early. One of the earliest varieties. Small cob and dwarf in growth. Pkt., 10c; 1/2 lb., 20c; 1 lb., 35c.

Country Gentlemen. One of the best for home use. Small white cob densely covered with splendid white grains; average eight to nine inches. Pkt., 10c; 1/2 lb., 20c; 1 lb. $35 \mathrm{c} ; 10$ lbs., $\$ 3.00$.

Black Mexican. The sweetest, richest and tenderest of all sweet corn. Turns black only when too old for table use. Pkt., 10c; 1,12 lb., 20c; 1 lb., 35c; 10 lbs., $\$ 3.00$.

Golden Bantam. As a sweet corn Golden Bantam is unsurpassed. Golden Bantam is a dwarf, early variety, growing 4 to 5 feet in height; golden yellow in color. Pkt., 10c; $1 / 2$ lb., 20c; I lb., 35c; 10 lbs., $\$ 3.00$.

Oregon Evergreen. One of the standard sorts for main crops everywhere. Ears large, deep grained, exceptionally tender and juicy. Pkt., 10c; $1 / 2$ lb., 20c; 1 lb., 35c; 10 lbs., $\$ 3.00$.

Wagner's Giant Bantam. Same as Golden Bantam except larger and more productive. Pkt., 10c; 1/2 lbs., 20c; 1 lb., 35c; 10 lbs., $\$ 3.00$.

Queens Golden Pop Corn. A large eared and handsome yellow popcorn; grains are large; pops perfectly white and very tender. 1 lb., 30c; 10 lbs., $\$ 2.50$.

White Rice. A popular and productive variety. $1 \mathrm{lb} ., 30 \mathrm{c}$; 10 lbs., $\$ 2.50$.

Hickory King. This corn is entirely distinct from all other varieties, having the largest grain with the smallest cob of any white corn. 1 lb., $25 \mathrm{c}$; 10 lbs., $\$ 2.00$.

Early Mastadon. The largest yellow corn grown. Has been known to produce over 200 bushels to an acre. 1 lb., 25c; 10 lbs., $\$ 2.00$.

Dwarf Milo Maize. Can be grown successfully either under irrigation or by the dry farming method. This corn can be picked for one-third less per acre than the tall Milo. I lb., 25c; 10 lbs., $\$ 2.00$.

Champion White Pearl. Stalk short and thick. The ear grows low on stalk, from seven to twelve inches in length, size averaging sixteen rows of grain. $1 \mathrm{lb}, 25 \mathrm{c}$; 10 lbs., $\$ 2.00$.

Prices on corn are subject to change without notice. If large quantities of corn is desired, send for samples and prices as all field seeds are subject to market fluctuation.

\section{Cucumbers}

Davis Perfection. Dark, glossy green, slim and symmetrical; length, ten to twelve inches. Hold color till nearly ripe. Fine quality for table use. Pkt., 10c; oz., 20c; $1 / 1$ lb., 50c; 1 lb., \$1.75.

Boston Pickling. One of the best pickling varieties; also excellent for slicing. Pkt., 10c; oz., 20c; 1/4 lb., 50c; 1 lb., \$1.75.

Early Green Cluster. Vine hardy, early and quite productive; extensively used for pickling. Pkt., 10c; oz., 20c; 1/4 lb., 50c; 1 lb., $\$ 1.75$.
Lemon. Gets its name from its shape; verly early and quite popular. Pkt., 10c oz., 25c; 1/4 lb., 75c; I lb., $\$ 2.50$.

Long Green. Long and crisp. Pkt., 10c; oz., $20 \mathrm{c}$; $1 / 4$ lb., 60c; 1 lb., $\$ 2.00$.

Nichol's Medium Green. One of the best general purpose cucumbers; symmetrical, deep in color. Pkt., 10c; oz., 20c; $1 / 4 \mathrm{lb}$. $50 \mathrm{c} ; 1 \mathrm{lb} ., \$ 1.75$.

\section{Kale}

Dwarf Curled Scotch. Very hardy variety; excellent for spring use. Pkt., 10c; oz., 20c ; $1 / 4$ lb., 50c; 1 lb., $\$ 1.50$

Jersey. Of vigorous growth, grown for chicken stock only. Pkt., 10c; oz., 20c; $1 / 4$ lb., $45 \mathrm{c}$; 1 lb., $\$ 1.25$.

Thousand Headed Kale. An excellent food for poultry; an immense yielder. Crops have yielded as high as 60 tons of green to the avre. Anyone having poultry should plant it. Pkt., 10c; oz., 20c; 1/4 1b., 45c;

1 lb., $\$ 1.25$.

\section{Lettuce}

Iceberg. A splendid head lettuce. For summer planting; compact, tender, crisp creamy white heads. Grows a solid head in midsummer $\mathrm{Pkt}, 101 / 2 \mathrm{c}$; oz., $20 \mathrm{c}$; $1 / 4$ lb., 65c; 1 lb., $\$ 1.75$.

Los Angeles Market. Forms a large, tight head of very sweet and tender leaves. Is unsurpassed in quality or yield by any of the heading varieties. Pkt., 10c; oz., 30c $1 / 4$ lb., $\$ 1.00 ; 1$ lb., $\$ 3.00$.

New York. The most profitable lettuce grown. Exclusively used by hotels in Los Angeles. It is hardy, uniform size, crisp and tender. We recommend this variety very highly. Pkt., 10c; oz., 30c; $1 / 4$ lb., $\$ 1.00$; 1 lb., $\$ 3.00$.

Early Curled Simpson. A very popular early sort. Forms large, loose heads. Pkt., $10 \mathrm{c}$; oz., $20 \mathrm{c}$; $1 / 4$ lb., $50 \mathrm{c}$; 1 lb., $\$ 1.50$.

Prizehead. Large, loose-headed sort; leaves tinged with brown; very heavy. Pkt., $10 \mathrm{c}$; oz., 20c; $1 / 4$ lbs., $50 \mathrm{c}$; I lb., $\$ 1.50$.

Chicken Lettuce. Loose leaf sort, grown mainly for poultry and rabbits; very large leaves. Pkt., 10c; Oz., 20c; 1/4 lb., 50c; lb., $\$ 1.50$.

\section{Muskmelons}

Hon?y Dew. Color of the skin is a light, creamy yellow, the rind being very thin. It is a long keeping melon. We highly recommend this variety. Pkt., 10c; oz., $25 \mathrm{c}$; $1 / 4$ lb., 85c; I lb., $\$ 2.00$.

Thoroughbred Rocky Ford. An improvement over the Rock Ford. A very fine va. riety. Pkt., 10c; oz., 20c; $1 / 4$ lb., 50c; l lb. $\$ 1.50$.

Pineapple. Large size, early, flesh green and rich flavor. Excellent shipper. Pkt., 10c; oz., 20c; 1/4 lb., 60c; I lb., \$1.75.

Tip Top. One of the best known varieties; salmon flesh; grown extensively in the $1 \mathrm{~m}$ perial Valley districts. Pkt., 10c; oz., 20c; $1 / 4$ lb., 50c; 1 lb., $\$ 1.50$.

Persian. One of the large varieties of Muskmelons; very thin rind and excellent flavor; color, salmon. Pkt., 10c; oz., 20c; $1 / 4$ lb., 80c; i lb., $\$ 2.50$.

Banana. Flesh salmon and exquisitely flavored. Brings a high price in markets. Pkt., 10c; oz., 20c; 1/4 lb., 50c; 1 lb., \$1.50. Rocky Ford Pollock. The latest improved type of the popular Rocky Ford. Perfect shipping qualities. Very good flavor. Pkt. $10 \mathrm{c}$; oz., $20 \mathrm{c}$; $1 / 4$ ib., $65 \mathrm{c}$; 1 lb., $\$ 2.00$.

Golden Honey. A golden fleshed Honey Dew. The flesh is a rich golden color, very thick and sweet. Pkt., $10 \mathrm{c}$ oz., 30c; 1/4 lb., $\$ 1.00$; 1 lb., $\$ 3.00$. 


\section{Casabas}

Santa Claus. The latest melon grown. Thin, hard skin with yellowish brown markings, flesh light green, good flavor. Can be picked in September or October; will keep for several months. Pkt., 10c; oz. $25 \mathrm{c}$; $1 / 4$ lb., $85 \mathrm{c}$; 1 lb., $\$ 2.50$.

This melon was introduced by J. B. Wag. ner from ltaly in 1902.

Winter Pineapple. A large, late melon; corrugated skin, green flesh of pronounced pineapple flavor. Flavor is greatly improved by being stored in a cool place. Pkt., 10c; oz., 25c; $1 / 4$ lb., $85 \mathrm{c}$; $1 \mathrm{lb}$., $\$ 2.50$.

Golden Beauty. A variety of winter pineapple which it resembles in every way except color. Pkt., 10c; oz., 25c; $1 / 4$ lb., $85 \mathrm{c}$; 1 lb., $\$ 2.50$.

\section{Watermelons}

Klondyke. The sweetest and most prolific melon. Seed one-half as large as in other melons; good for local consumption or shipment. Pkt., 10c; oz., 25c; 1/4 lb., 85c; 1 lb., $\$ 2.50$.

Chilian. (White seeded.) Melon of merit; extra solid, crisp, sugary; a favorite because of its remarkable eating and shipping qualities. Pkt., 10c; oz., 20c; $1 / 4$ lb., 40c; 1 lb., $\$ 1.50$.

Chilian. (Black seeded.) Possesses a rich, fruity flavor; has all the good qualities of the white seeded, a trifle sweeter. and has a very thin rind. We advise plant. ing this variety. Pkt., $10 \mathrm{c}$; oz., $20 \mathrm{c}$; $1 / 4 \mathrm{lb}$., $50 \mathrm{c} ; 1$ lb., $\$ 1.50$.

Black Seeded Angeleno. A combination of the unexcelled qualities of the famous Angeleno and the favorite seeded Chilian. Pkt., 10c; oz., 20c; $1 / 4$ lb., 65c; 1 lb., $\$ 2.00$.

Tom Watson. Exceedingly popular melon; fruit large, thin rind, good shipper; small seed area. Pkt., 10c; oz., 20c; $1 / 4$ lb., 50c; $1 \mathrm{lb} ., \$ 1.50$.

Yellow-Fleshed Ice Cream. Very long oblong shape; flesh a beautiful yellow; delicious flavor; different from any other variety. Pkt., 10c; oz., 20c; $1 / 4$ lb., 50c; 1 lb., $\$ ! .25$.

\section{Okra}

Early Dwarf. Stocky growth, heavy bearer; a greenish-white color; tender, and of good flavor. Pkt., 10c; oz., 20c; 1/4 lb., $45 \mathrm{c} ; 1$ lb., $\$ 1.25$.

White Velvet. Pods round, smooth, free from seams; tender, and of good flavor. Pkt., 10c; oz., 20c; $1 / 4$ lb., 45c; 1 lb., \$1.25.

Long Green. Later and more productive ribbed pods. Pkt., 10c; oz., 20c; $3 / 4$ lb., $45 \mathrm{c} ; 1$ lb., $\$ 1.25$.

\section{Onions}

Riverside Sweet Spanish. A most popular variety owing to its mildness in flavor; can be eaten like an apple. Good keeper; immense size. Commands a high price in any market. We unhesitatingly recommend this variety for either home or commercial growing. Pkt., 10c; oz., $\$ 1.00 ; 1 / 4$ lb., \$3.35; 1 lb., $\$ 10.00$.

Australian Brown. The flesh is pure white, close layered, juicy and tender, growing to a good size. Hardy, does especially well in the South. Pkt., 10c; oz., 20c; $1 / 4$ lb., $60 \mathrm{c}$; 1 lb., \$1.75.

Bermuda Yellow Onion. More extensively grown for early market than any other. A large onion, very mild pale straw color Pkt. 10c; oz., 40c; 1/4 lb., \$1.35; 1 lb., \$4.00.
Chrystal White Wax. A large white onion of the Bermuda type. Pkt., 10c; oz., $50 \mathrm{c}$ $1 / 4$ lb., $\$ 1.65 ; 1$ lb., $\$ 5.00$.

Southport White Globe. A great yielder; fine grained and firm. Pkt., 10c; oz., $40 \mathrm{c}$; $1 / 4$ lb., $\$ 1.35 ; 1$ lb., $\$ 4.00$.

White Portugal or Silver Skin. One of the leading white sorts, splendid variety for market garden. Pkt., 10c; oz., 40c; $1 / 4$ lb., $\$ 1.35 ; 1$ lb., $\$ 4.00$.

Yellow Globe Danvers. A well known early onion of fine quality. Pkt., $10 \mathrm{c}$; oz. $20 \mathrm{c} ; 1 / 4$ lb., 65c; 1 lb., $\$ 2.00$.

Bunching Onion. Produces small green onion; pull while medium size before the bulb has formed. Pkt., 10c; oz., 35c; 1/4 lb., $\$ 1.20 ; 1$ lb., $\$ 3.50$.

\section{Parsley}

Champions Moss Curled. Vigorous; com pact; excellent for garnishing and flavoring leaves fine and crisp. Pkt., 10c; oz., 20c; $1 / 4$ lb., 60c; I lb., $\$ 1.75$.

Plain Parsley. Leaves flat, deeply cut but not curled; very dark green in color and very hardy. Pkt., 10c; oz., 20c; $1 / 4$ lb., 50c; 1 lb., $\$ 1.50$.

\section{Parsnips}

Hollow Crowned. The best all around parsnips; excellent for table or stock. A sure cropper. Pkt., 10c; oz., 20c; $1 / 4$ lb. $65 \mathrm{c} ;$ I lb., $\$ 2.00$.

\section{Peas}

American Wonder. Stocky, erect and very prolific. Especially good for the home garden. Pkt., 10c; 1/2 lb., 20c; 1 lb., $35 \mathrm{c}$.

Dwarf Telephone. A dwarf growing strain of the Telephone variety. Pkt., 10c; $1 / 2 \mathrm{lb}$. $20 \mathrm{c}$; $1 \mathrm{lb} ., 35 \mathrm{c}$.

McLean's Little Gem. A dwarf, first early pea of unusual value and excellent flavor. Pkt., 10c; 1/2 lb., 20c; 1 lb., $35 \mathrm{c}$.

Admiral or Senator. A new sort. It is a good variety, thick green foliage, bears well large, well filled pods. Pkt., $10 \mathrm{c}$; $1 / 2 \mathrm{lb}$. $20 \mathrm{c} ; 1$ lb., $35 \mathrm{c}$.

Stratagem. Keeps well after picking. The majority of peas purchased locally are of this variety. It grows without any support. Pkt., 10c; 1/2 lb., 20c; 1 lb., 30c.

Yorkshire Hero. Its strong vigorous growth makes this pea especially valuable to the market gardner; grows bush; yields prodigiously. Pkt., 10c; $1 / 2$ lb., 20c; 1 lb. $35 \mathrm{c}$.

Alderman. Well flavored pea; vines tall and branching; bearing large deep green pods. Pkt., 10c; 1/2 lb., 20c; $1 \mathrm{lb}, 35 \mathrm{c}$.

Telephone. A fine wrinkled pea growing about four feet high; very prolific and pods large. Pkt., 10c; 1/2 1b., 20c; 1 lb., 35 c.

\section{Peppers}

Cayenne. Pods small, coral red when ripe: very hot and strong; best kind for reasoning pickles. Pkt., 10c; oz., $80 \mathrm{c}$; $1 / 4$ lb., $\$ 2.65 ; 1$ lb., $\$ 8.00$.

Mexican Chili. Of medium size, pear shaped; turns bluish black when dried. Pkt. 10c; oz. 50c; 1/4 lb., \$1.65; 1 lb., \$4.50.

Perfection Pimento. All home gardens should include Pimento Peppers. Pkt., 10c; oz., 60c; 1/4 lb., $\$ 2.00 ; 1$ lb.. $\$ 6.00$.

Chinese Giant Pepper. A pepper of exceptional merit; very mild and an ideal variety for the home garden; fine texture and ideal for stuffing pepper. Pkt., 10c; oz., $80 \mathrm{c}$; $1 / 1$ lb., $\$ 2.50 ; 1$ lb., $\$ 8.00$. 


\section{Pumpkins}

Kentucky Field Pumpkin. A heavy fleshed remarkably sweet pumpkin. A splendid keeper; fine sort for family use and market. Pkt., 10c; oz., 20c; 1/4 lb., 35c; 1 lb., $\$ 1.00$.

Boston Pie or Small Sugar. A very popular table variety. Pkt., $10 \mathrm{c}$; oz., $20 \mathrm{c}$; $1 / 4 \mathrm{Ib}$., $50 \mathrm{c} ; 1 \mathrm{lb} ., \$ 1.50$.

Big Cheese. Best stock pumpkin and best keeper. Plkt., 10c; oz., 20c; 1/4 lb., 35c;

1 Ib., $\$ 1.00$.

Mammouth Tours Pumpkin. Attains immense size. A fine stock variety; its rich flavor makes it also valuable for canning and home use. Rapid grower. Pkt, 10c; oz., $20 \mathrm{c} ; 1 / 4$ lb., $35 \mathrm{c}$; 1 lb., $\$ 1.00$.

Sweet or Early Sugar. This is the small sweet pumpkin that has made the New England States famous for their pies. Pkt., $10 \mathrm{c}$; oz., 20c; $1 / 4$ lb., 50c; I lb., \$1.50.

Connecticut Field or Jack O'Lantern. A fine variety for dairy ranches adding to quality of milk and butter. Pkt., 10c; oz., $20 \mathrm{c} ; 1 / 4$ lb., $35 \mathrm{c}$; 1 lb., $\$ 1.00$.

\section{Radishes}

California Mammoth White. A winter sort; flesh, white, firm and excellent flavor. Pkt., 10c; oz., 20c; $1 / 4$ lb., 50c; 1 lb., $\$ 1.50$.

Early Long Scarlet Short Top. Very brittle and sweet; matures in twenty-five to thirty days; adapted to the home or market garden. Pkt., 10c; oz., 20c; $1 / 4$ lb., $50 \mathrm{c}$; 1 lb., $\$ 1.50$.

Japanese Summer Radish. Grows as long as twenty-four inches; very tender, mild and of excellent flavor. Pkt., 10c; oz., 25c; $1 / 4$ lb., $85 \mathrm{c} ; 1$ lb., $\$ 2.50$.

Scarlet Globe. Very early; a little longer than round; small top, brilliant deep scarlet. Pkt., 10c; oz., 25c; 1/4 lb., 50c; 1 lb., $\$ 1.50$.

French Breakfast. An early variety with good flavor and very pretty; a favorite wherever known. Pkt., 10c; Oz., 25c; 1/4 lb., $50 \mathrm{c}$.

Mixed Radishes. Supply a nice assortment for table; all sizes and colors.

\section{Rhubarb}

Wagner's Giant Crimson. Pkt., 10c; oz., $\$ 1.60 ; 1 / 4$ lb., $\$ 5.00 ; 1$ lb., $\$ 16.00$.

Dodge. Pkt., 10c; $1 / 4$ lb., $\$ 1.50 ; 1 / 2$ lb., $\$ 2.50 ; 1$ lb., $\$ 4.00$.

\section{Squash}

Long White Vegetable Marrow. An English variety of delicious flavor. Pkt., $10 \mathrm{c}$; oz., 20c; $1 / 4$ lb., 60c; I b., \$1.75.

Summer Crook Neck. This is the richest summer squash, very early and productive. Pkt., 10c; oz., 20c; 1/4 lb., 50c; i lb., \$1.50.

Banana Squash. Firm and solid; flesh good quality. Pkt., 10c; oz., 20c; 1/4 lb. $50 \mathrm{c} ; 1$ lb., $\$ 1.50$.

Fordhook. One of the best late summer varieties. Thick skin, bright yellow. Heavy meat. Pkt., 10c; oz., 20c; $1 / 4$ lb., 60c; 1 lb., $\$ 1.75$.
Hubbardb. The best winter variety grown. Vigorous and productive; richly flavored, yellow flesh. Pkt., 10c; oz., 20c; $1 / 1 / 1$ lb., 50c; 1 lb., $\$ 1.50$.

\section{Spinach}

Bloomdale. Thick, dark green wrinkled leaves, very hardy. The earliest and best for autumn use. Pkt., 10c; oz., 15c; 1/4 lb., $20 \mathrm{c} ; 1$ lb., $60 \mathrm{c}$.

Long Standing. Leaves large, thick and crimped with a fleshy appearance. Matures quickly; very tender and fine flavored. Pkt., $10 \mathrm{c}$; oz., 15c; 1/4 lb., 20c; 1 lb., 60c.

\section{Tomatoes}

Beefsteak. This is an exceedingly popular variety. One of the best tomatoes grown. lt is very prolific. Bright red color, firm substantial meat, luscious flavor. Pkt., $10 \mathrm{c}$; oz., 70c; $1 / 4$ lb., $\$ 2.35 ; 1$ lb., $\$ 7.00$.

Bonny Best. Extra early, scarlet, round variety of great value. Fruit of even size. Pkt., 10c; oz., 40c; $1 / 4$ lb., $\$ 1.25 ; 1$ lb., $\$ 4.00$.

Globe. A very nearly round tomato of good quality. Early maturing. Pkt., $10 \mathrm{c}$ : oz., $45 \mathrm{c} ; 1 / 4$ lb., $\$ 1.50 ; 1$ lb., $\$ 4.50$.

Ponderosa. Very smooth and solid; very large size. Pkt., 10c; oz., $85 \mathrm{c} ; 1 / 4 \mathrm{lb}$., $\$ 2.25$; 1 lb., $\$ 6.50$.

San Jose Canner. Used extensively for canning purposes; good market garden tomato. Pkt., 10c; oz., 75c; $1 / 4$ lb., $\$ 2.50$ I lb., $\$ 7.50$.

Stone. The old favorite; best for the market. Pkt., 10c; oz., 40c; $1 / 4$ lb., \$1.35; I ib., $\$ 4.00$.

Spark's Earliana. Early prolific and very solid; noted as a good shipper. Pkt., 10c : oz., $40 \mathrm{c}$; $1 / 4$ lb., $\$ 1.35 ; 1$ lb., $\$ 4.00$.

\section{Turnips}

Extra Purple Top Milan. A week earlier than the earliest other sorts. Medium size, flat and thick, purple top, white flesh. It accommodates itself to either Spring or Fall. Pkt., 10c; oz., 20c; 1/4 lb., 40c; 1 lb., $\$ 1.25$.

Early White Egg. An egg shaped variety for Spring and Fall sowing, flesh firm, fine grained, mild and sweet. Pkt., $10 \mathrm{c}$; oz., $20 c ; 1 / 4$ lb., 40c; 1 lb., \$1.25.

Early Snowball. Grows even in size and is most completely described by its name; pure white and round as a ball. Crisp and mellow. Pkt., 10c; oz., 20c; 1/4 lb., 40c; I lb., \$1.25.

Red Top White Globe. A large rapid growing sort, flesh pure white and best flavor of any turnip; skin white with red top. Pkt., 10c; oz., 20c; 1/4 lb., 40c; 1 lb., $\$ 1.25$.

Purple Top Strap Leaf. Very productive; matures quickly; flesh white and sweet. Pkt., 10c; oz., 20c; 1/4 lb., 40c; 1 lb., \$1.25.

Improved Yellow Purple Top Rutabagas. Standard sort both for stock feeding and table use. Flesh yellow, solid and sweet. Pkt., 10c; oz., 20c; 1/4 lb., 45c; 1 lb., \$1.25.

Plant Rhubart for profit and let us hear from you if there is any point about it not perfectly clear. Visitors always welcome at office of growing field. 


\section{PLEASE USE THIS ORDER SHEET \\ (Read Carefully When You Order)}

We advise sending plants by express when possible. Express is usually cheaper than Parcel Post, besides they are responsible for loss or injury by delay.

If you wish flants to be prepaid, add 10 per cent to your order; for instance, to every $\$ 1.00$ add $10 \mathrm{c}$, to a $\$ 5.00$ order add $50 \mathrm{c}$, etc., and we will guarantee safe arrival of plants and prepay express or parcel post charges. In all cases give both express and parcel post address. Stock in cans or balls only sent charges collect, never prepaid.

TRUE TO NAME: While we use every precaution to have all plants, bushes, et.., true to name, we will not be responsible for any sum greater than the cost of the stock, should any prove otherwise than as represented. And in no case, where, for plopagating purposes, or for filling orders, we secure seeds, plants, scions, cuttings or buds from others, do we assume responsibility or give any guarantee whatever.

WAGNER NURSERIES, Pasadena, California.

Gentlemen: Enclosed please find

for the following order of plants or seerls.

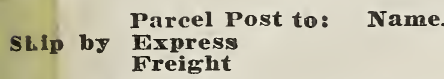

Parcel Post to: Name

Ship by Express

Freight

County

Town................................... State.

N

Name.

I'ost Office (R. F. D., P. O. Box, or Street and No.).

J'own

State

THINGS TO REMEMBER. Write your address plainly. Money may be sent at cur risk by Post Office money order, Express money order, check, or stamps for amounts less than one dollar. We do not deliver free any plants or trees. 5 at 10 rite, 50 at 100 rate, 500 at 1000 rate on everything in this catalogue.

PLEASE WRITE YOUR LETTER ON A SEPARATE SHEET OF PAPER. THEN YOUR ORDER AND ANSWER WILL NOT BE DELAYED. 


\section{Please observe when ordering}

Use order sheet, fill out carefully, and much delay and trouble will be avoided. We fill orders as soon as received, if the stock is ready. Customers who wish their order or any part of it booked for shipping at a later date should so state.

COMPLAINTS. If any error has been made in your order claim must be made within 5 days after receipt of the goods. or same will not be entertained.

SUBSTITUTION. Please state whether substitution will be permitted otherwise we will feel at liberty in filling the order to use other varieties as near similar as possible. It very often happens on orders of assorted varieties, for a home orchard, that it is necessary to make substitutiors. On orders for commercial planting substitutions are never made without first obtaining the consent of the purchaser.

TERMS. Cash with order. Orders sent C. O. D., will be filled, provided onethird of the amount is sent with the order. At our prices we cannot afford to do a credit business.

REFERENCES. As to our reliability we refer to our 30 years specializing in Rhubarb, berries, and small fruits. Our thousands of pleased customers; Dunn and Bradstreet's Commercial Rating Agencies; any bank in Pasadena.

TRUE TO NAME. While we use every precaution to have all plants, bushes, etc., true to name we will not be responsible for any sum greater than the cost of the stock, should any prove otherwise than as represented. And in no case, where, for propagating purposes, or for filling orders, we secure seeds, plants, scions, cuttings or buds from others, do we assume responsibility or give any guarantee whatever.

ALWAYS GIVE FULL ADDRESS. This is important; write your name plainly, your postoffice, county and state.

SHIPPING INSTRUCTIONS. Give your nearest express office and railway station, stage route or transportation company, and how you wish us to ship. Where possible we advise sending stock by express. If you wish stock by parcel post add $10 \%$ additional to your remittance or 10 cents for every dollar's worth of stock or fraction of a dollar, and we prepay charges except when canned, balled or potted, which must be sent collect.

IMPORTANT. There are a great many varieties of fruits advertised in most catalogs. It is very confusing to fruit growers inasmuch as they are generally described as the best, and sone are sure to disappoint the purchaser. We call your attention to the fact that we list only varieties that will give entire satisfaction to the planter. We have grown and tested hundreds of varieties of fruits, and have kept discarding the worthless varieties until our catalog is used to list the varieties of merit, and varieties that will give the planter satisfactory returns.

We wish to thank our old customers for their patronage during the past years and it is our sincere desire to merit it in the future and trust that we will have the pleasure of serving you this coming season. This catalog is printed for your benefit and we ask you to read and study it carefully. We will be glad to furnish you with any aditional information if you wish it at any time.

WAGNER NURSERIES 